\title{
Review and palaeoecological analysis of the late Tremadocian - early Floian (Early Ordovician) cephalopod fauna of the Montagne Noire, France
}

\author{
Björn Kröger*, ${ }^{*}$ and David H. Evans ${ }^{2}$ \\ ${ }^{1}$ Museum für Naturkunde Berlin, Invalidenstraße 43, 10115 Berlin, Germany. E-mail: bjoekroe@gmx.de \\ ${ }^{2}$ Geology, Landscape and Soils Team, Natural England, Northminster House, Peterborough, PE1 1UA, UK. \\ E-mail: david.evans@naturalengland.org.uk
}

Received 29 January 2010

Accepted 1 September 2010

Published 21 February 2011

\section{Key Words}

\author{
Gondwana \\ Palaeozoic \\ palaeoecology \\ Orthocerida \\ Ellesmerocerida
}

\begin{abstract}
The Early Ordovician successions of the southern Montagne Noire consist of a thick sequence of predominantly siliciclastic sediments of which the late Tremadocian St. Chinian Formation and the earliest Floian La Maurerie Formation contain a comparatively rich and abundant cephalopod association. The cephalopods of the St. Chinian and La Maurerie Formation are interpreted as generally authochthonous, representing a fauna which originally lived in the open water above the sediments or related to the sea bottom. The cephalopod associations of the St. Chinian and La Maurerie formations are similar to other contemporaneous assemblages known from higher palaeolatitudes and associated with deeper depositional settings. They are composed almost exclusively of longiconic orthocones, in this case predominantly of eothinoceratids and baltocerids. The occurrences of Annbactrocera, and Bactroceras in the St. Chinian Formation are at present the earliest unambiguous reports of the Orthocerida. The available data suggest an initial expansion of orthoceroid cephalopod faunas from open water habitats of high paleo-latitudes, and a subsequent expansion on the carbonate platforms during the Floian. The presence of the eothinoceratid Saloceras in abundance demonstrates the Gondwanan affinity of the assemblage whilst adding further support for the presence of a 'Saloceras realm' that may have extended along the margins of East and West Gondwana at least into intermediate latitudes. The following new taxa are proposed: Annbactroceras n. gen., Annbactroceras felinense n. sp., Cyclostomiceras thorali n. sp., Felinoceras n. gen., Felinoceras constrictum n. sp., Lobendoceras undulatum n. sp., Rioceratidae n. fam., Saloceras murvielense n. sp., Thoraloceras n. gen., Thoraloceras bactroceroides $\mathrm{n}$. sp.
\end{abstract}

\section{Introduction}

By comparison with the relatively diverse Early Ordovician cephalopod faunas that lived in association with the low latitude carbonate platforms (e.g. Laurentia [Flower 1964]; Siberia [Balashov 1961]; China [Chen 1976]), those of the high latitude margins of Gondwana are of relatively low diversity, generally poorly known, and where known, often in need of revision. Of those high latitudinal assemblages most recently revised or newly described in detail (Evans 2005; Gnoli \& Pillola 2002; Marek et al. 2000), all seem to be characterized by the presence (often in abundance) of members of the family Eothinoceratidae. In revising the early ordovician cephalopod faunas of England and Wales (eastern Avalonia), Evans (2005) recorded the presence of the Orthoceratoidean families Baltoceratidae, Polymeridae and Troedssonellidae from sediments of early Floian age. Until now, this particular fauna contained the oldest unequivocal record of the Orthoceratoidea. One interpretation that may be put upon their occurrence in such a location is the possibility that the Orthoceratoidea might have originated in a region of high palaeolatitude. Such an interpretation, based upon a single geographical datum, remains tentative.

\footnotetext{
* Corresponding author
} 
On a visit to the University of Lyon during the latter part of 2008, one of us (BK) was introduced to the extensive collection of fossil cephalopods from the early Ordovician of the Montagne Noire, Hérault, Southern France. It became clear that this material, although preserved as moulds, is largely undeformed, and consists of a diverse assemblage comprised predominantly of longicones, in which members of both the Eothinoceratidae and Orthoceratoidea appear to be represented. This assemblage, which has not been revised since its original description by Thoral (1935) is clearly of significance in contributing to a better understanding of the composition, distribution and palaeobiogeographical relationships of the early Ordovician cephalopod faunas of the high latitude Gondwanan margins. Furthermore, the fauna also pushes the age of the oldest unequivocal members of the Orthoceratoidea into the late Tremadocian.

\section{Material and methods}

With the exception of the type material described by Thoral, which is held at the University of Montpellier (prefix USTM-ACI), all the material described below is from the Geological Collections, Université Claude Bernard, Lyon 1 and has the prefix FSL. None of the type material described by Thoral was used directly in this study and only his illustrations and descriptions (Thoral 1935, 1946) were referred to. This is not considered to detract from the value of the study as the size and range of the collections at Lyon are such that they contain material directly comparable with Thoral's type specimens as well as providing data related to intra-specific variation.

Apart from a few specimens that had been sectioned with a saw at some time in the past, none of the material studied has been prepared in any way. All of the material consists of the external and internal moulds of body-chambers and phragmocones preserved in siliceous concretions or nodules. The visible features of all the specimens are adventitious and result from the breaking open of the concretions.

All measurements were taken using vernier calipers or a calibrated graticule inserted into one of the eyepieces of a binocular microscope. Unless otherwise indicated, the specimens were coated with ammonium chloride and then photographed using a Canon EOS -300D SLR combined with a $100 \mathrm{~mm}$ macro-lens. In a few specimens, details of the structure of the siphuncle were recorded with a Nikon - attached to a microscope with the specimen submerged in a high contrast fluid.

\section{Geological setting and stratigraphic framework}

Ordovician rocks in the southern part of the Montagne Noire form a series of east-north-easterly, west-southwesterly trending outcrops extending from the Landeyran Valley in the east to the vicinity of Lastours in the west (Fig. 1). These rocks occur in a series of thrust slices that form a component of the southerly directed, Minervois, Pardailhan and Mont Peyroux nappes lying to the south of the Agoût Massif which forms the axial zone of the Montagne Noire. The thrust units and nappes consist of rocks ranging from Cambrian to Early Carboniferous in age which were derived from north of the axial zone during the mid-Carboniferous collision of the Gondwanan promontory of the Catalan Craton with several micro-continents that now form part of the internal zone of the French Variscan belt (Demange 2001).

The Early Ordovician successions of the southern Montagne Noire consist of a thick sequence of predominantly siliciclastic sediments (sandstones, siltstones, mudstones and shales) that have been referred to as flysch (e.g. Boyer \& Guiraud, 1964), but are generally regarded as having been deposited in a range of distal to more proximal shelf environments (Álvaro et al. 2003; Noffke \& Nitsch 1994; Vizcaïno et al. 2001). A variety of lithostratigraphical schemes have been proposed and the scheme used here is that of Vizcaïno et al. (2001) in which the succession is divided into six formations (Fig. 2), that range in age from Tremadocian to Floian. The youngest Ordovician strata exposed in Montagne Noire (Landeyran Formation) have been dated as upper Floian based on their graptolite faunas (J.C. Gutiérrez-Marco, unpubl. data): the Apatokephalus incisus Zone (lower part of the Landeyran Formation)
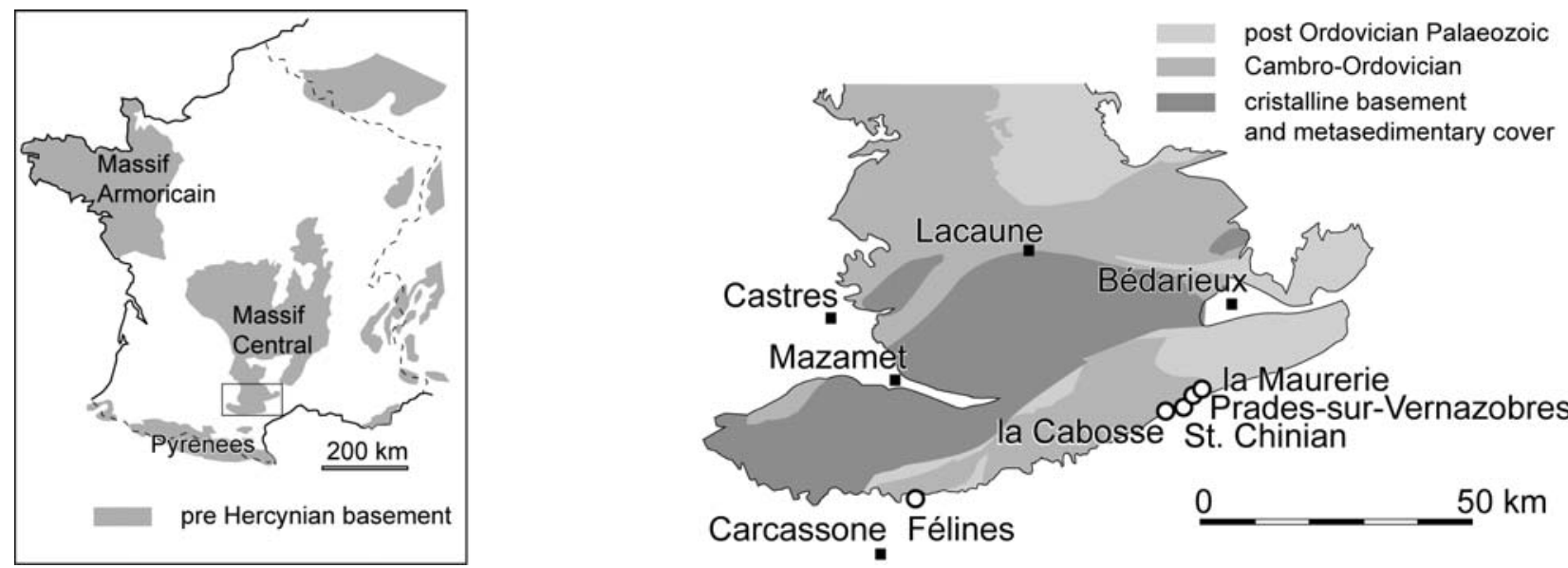

Figure 1. Generalized map of most important cephalopod localities (empty circles) of the Early Ordovician of the Montagne Noire. Modified from Carte géologique imprimée 1/1 000 000, 6ème édition révisée (Bureau de Recherches Géologiques et Minières). 

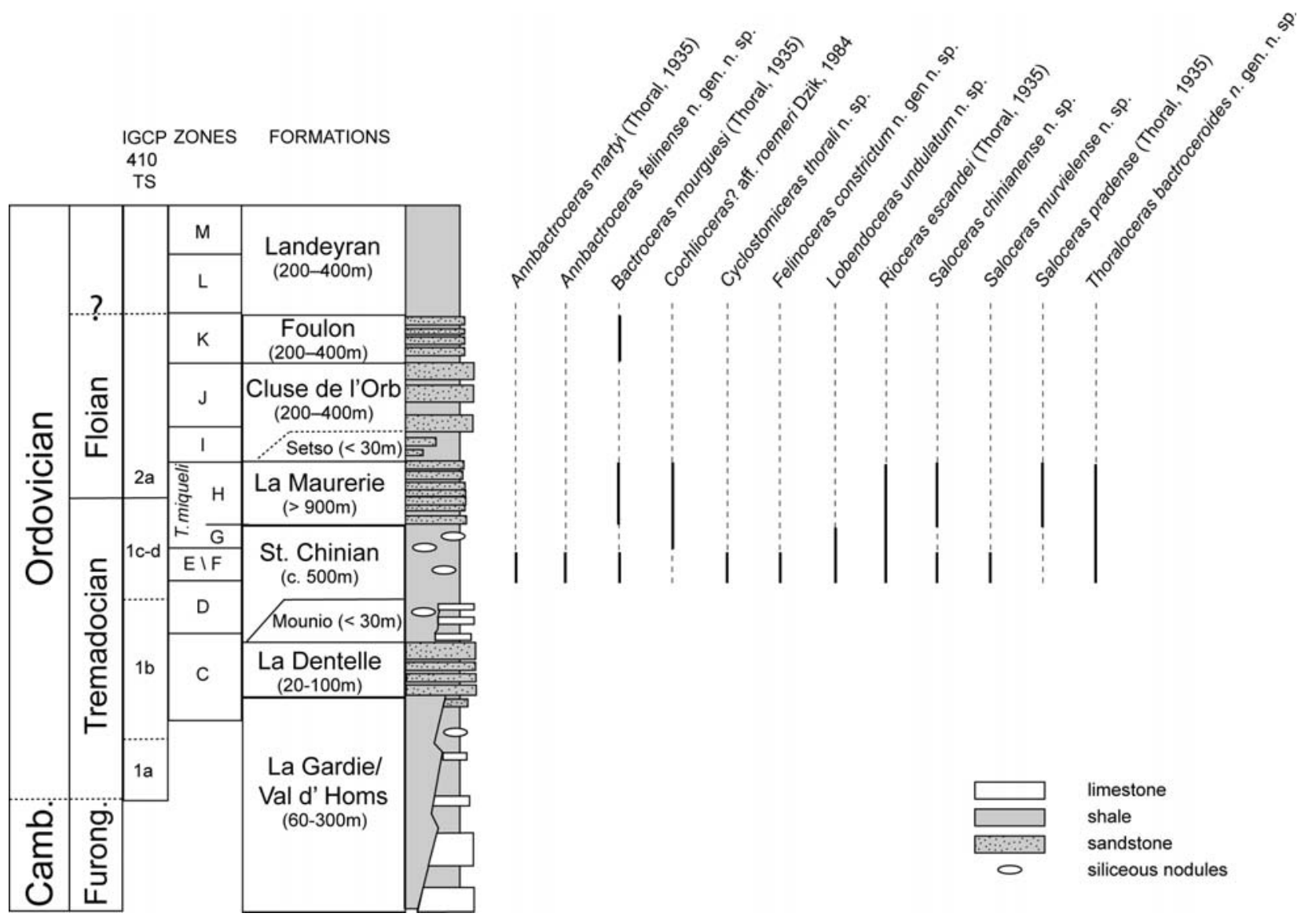

Figure 2. Stratigraphic ranges of cephalopods of the Early Ordovician of the Montagne Noire. Section modified from Vizcaïno and Álvaro (2003). IGCP 410 TS, Time Slices of Webby et al. (2004).

corresponds to the densus graptolite zone, and the Hangchungolithus primitivus Zone (upper part of the Landeyran Formation) would be equivalent to the elongatus graptolite zone]. The succession has been divided biostratigraphically into a series of 'faunizones' (A-M) based upon trilobite associations following the work of Courtessole et al. (1981, 1983, 1985, 1991). These have been further refined as biozones after named taxa (Vizcaïno \& Alvaro 2003), but the presence of many barren horizons within the succession, as well as the tectonic disruption of the succession have acted as obstacles to the development of a refined biostratigraphy that correlates well with regions outside of the Montagne Noire. The diverse and often abundant faunas consist of a range of trilobites, echinoderms, molluscs and graptolites amongst other taxa. Trends in trilobite and echinoderm diversity appear to be related to substrate and relative position on the slope to shore transect, with the most diverse assemblages associated with the finergrained sediments of the more distal locations represented by the St Chinian and Landeyran formations. The palaeobiogeographical relationships of these faunas based on the echinoderm assemblages are with parts of peri-Gondwana (eastern Avalonia) and adjacent parts of Gondwana (Morocco) (Vizcaïno et al. 2001), whilst the trilobites show a high degree of endemism, but are generally characteristic of western Gondwana and peri-
Gondwana and at some horizons indicate exchanges with Baltica (Tortello et al. 2006; Vizcaïno \& Alvaro 2003).

With a few exceptions, Lower Ordovician cephalopods of the Montagne Noire region are known only from the St. Chinian and La Maurerie formations. Studies of the agnostid faunas of the Montagne Noire successions (Tortello et al. 2006) suggest that the St. Chinian Formation (Euloma filacovi Zone = faunizone " $F$ " and the Asaphelina barroisi berardi + Taihungshania miqueli subzone = faunizone "G") is late Tremadocian in age, whilst the La Maurerie Formation (Taihungshania miqueli acme Subzone = faunizone " $\mathrm{H}$ ") is early Floian in age. Thus the cephalopods described below are considered to range in age from the late Tremadocian to the early Floian.

\section{Faunal composition and depositional setting}

\section{St. Chinian Formation}

The St. Chinian Formation, of late Tremadocian age, consists of a monotonous succession of dark-grey claystones, and green siltstones with fine to mediumgrained sandstone intercalations and silicious nodules 
Table 1. Evenness of Tremadocian and Floian cephalopod collections. Note the low evenness of the total sample of the La Maurerie Formation compared with collections from platform carbonates of New York. Note also the high evenness of the Félines collection. The differences in species abundance pattern within the La Maurerie Formation probably reflect differences in individual horizons (see also Tab. 2, and text for discussion). $N=$ number of specimens; $S=$ number of species; $S_{\text {rarified }}$ rarified $S$ with census 55 specimens, lower and upper $95 \%$ confidence interval in parentheses; $J=H^{\prime} / \log (S)$; where $H^{\prime}$ is the Shannon-Wiener index of the sample. ${ }^{\#}$ without specimens from St. Chinian, ${ }^{*}$ raw data are from Kröger and Landing (2009).

\begin{tabular}{|c|c|c|c|c|}
\hline & $N$ & $S$ & S rarified & $J$ \\
\hline Tribes Hill Formation, New York, early Tremadocian* & 345 & 11 & $5.6(3.5-7.7)$ & 0.57 \\
\hline Rochdale Formation, New York, middle Tremadocian* & 147 & 8 & $5.6(3.6-7.6)$ & 0.56 \\
\hline Fort Cassin Formation, New York, Floian* & 72 & 13 & $11.3(9.1-13.4)$ & 0.66 \\
\hline St. Chinian Formation, Félines-Minervois, Hérault, late Tremadocian & 55 & 10 & 10 & 0.86 \\
\hline La Maurerie Formation, Hérault, early Floian (total ${ }^{\#}$ ) & 122 & 7 & $6.1(4.1-8.1)$ & 0.48 \\
\hline
\end{tabular}

reaching a thickness greater than $500 \mathrm{~m}$. Although the sandstone intercalations are often graded and exhibit erosive bases, bioturbation is common and primary sedimentary features are often lacking (Alvaro et al. 2003). Where present, the fossil fauna is abundant within the St. Chinian Formation although its distribution is sporadic. Preservation ranges from articulated shells, through to broken debris, whilst the assemblage comprises of trilobites, echinoderms, and brachiopods (Ubaghs 1970; Vizcaïno \& Lefebvre 1999; Vizcaïno \& Álvaro 2003; Álvaro et al. 2003). The formation is interpreted as a transgressive interval deposited below normal storm wave base in an outer platform environment (Álvaro et al. 2003). Cephalopods are common and diverse in the St. Chinian Formation. The diversity and the evenness of the cephalopod association of the St. Chinian Formation is higher than in the Tremadocian low palaeolatitude carbonates of New York (compare Kröger \& Landing 2009, tab. 1). However, in contrast to the Laurentian associations, the cephalopod assemblage in the St. Chinian Formation consists exclusively of slender orthocones. Remarkable is the dominance in abundance of Orthocerida (Tab. 2, Fig. 3), but endocerids and eothinoceratids are abundant, too. The high richness of the cephalopod assemblage is in accordance with the highly diverse trilobite and echinoderm assemblages reported by Vizcaïno \& Lefebvre (1999) and Vizcaïno \& Álvaro (2003). The high trilobite and echinoderm diversity is attributed to a transgressive trend throughout the period of deposition of

Table 2. Number of specimens collected from the St. Chinian, La Maurerie, and Foulon formations (Faunizones E/F, H, K respectively) from different localities of the Montagne Noire, France. A - Félines-Minervois, B - St. Chinian, C - Viane Bolo, La Rouvelane, D - Prades-sur-Vernazobres, school, E - Cabriéres, F - La Cabosse près Assignan, G - La Maurerie, H - Prades-sur-Vernazobres, I - Prades-sur-Vernazobres, Canto Cigale, J - Prades-sur-Vernazobres, La Borie des Pierils, $\mathbf{K}$ - Prades-sur-Vernazobres, Vigne Bolo, La Rouvelane, L - St. Chinian, M - Cabriéres. The pronounced differences in species abundance pattern between localities probably indicate differences in individual horizons within the Faunal-Zones, rather than bias in collecting practice, because all specimens come from nodules, often with several specimens per nodule, and the different species are morphologically very similar. This pattern indicates some potential for a future faunal analysis after more detailed, bed-by-bed collection.

\begin{tabular}{|c|c|c|c|c|c|c|c|c|c|c|c|c|c|}
\hline & A & $\mathrm{B}$ & C & D & $E$ & $\mathrm{~F}$ & G & $\mathrm{H}$ & I & J & $\mathrm{K}$ & L & M \\
\hline Fauni Zone & $\mathrm{F}$ & $\mathrm{F}$ & $\mathrm{F}$ & G & $\mathrm{H}$ & $\mathrm{H}$ & $\mathrm{H}$ & $\mathrm{H}$ & $\mathrm{H}$ & $\mathrm{H}$ & $\mathrm{H}$ & $\mathrm{H}$ & K \\
\hline Annbactroceras martyi (Thoral, 1935) & 4 & 1 & 1 & & & & & & & & & & \\
\hline Annbactroceras felinense n. gen. n. sp. & 1 & & & & & & & & & & & & \\
\hline Bactroceras mourguesi (Thoral, 1935) & 16 & & 1 & & 5 & & 1 & & 1 & 2 & 1 & 4 & 1 \\
\hline Cochlioceras? aff. roemeri Dzik, 1984 & & & & 6 & & & & 1 & 2 & & & & \\
\hline Cyclostomiceras thorali n. sp. & 2 & & & & & & & & & & & & \\
\hline Felinoceras constrictum n. gen. n. sp. & 2 & & & & & & & & & & & & \\
\hline Lobendoceras undulatum n. sp. & 11 & & & 1 & & & & & & & & & \\
\hline Rioceras escandei (Thoral, 1935) & 4 & 1 & & 12 & & 4 & & & 11 & & & & \\
\hline Saloceras chinianense n. sp. & 10 & & & & & 11 & 8 & & 71 & & & $(21)$ & \\
\hline Saloceras murvielense n. sp. & 3 & 1 & & & & & & & & & & & \\
\hline Saloceras pradense (Thoral, 1935) & & & & & & & & 1 & & & & 5 & \\
\hline Thoraloceras bactroceroides n. gen n. sp. & 2 & & & 1 & & & & & & 1 & & & \\
\hline Order, family, genus, indet sp. & & & & & & 1 & 1 & & & & & & \\
\hline
\end{tabular}




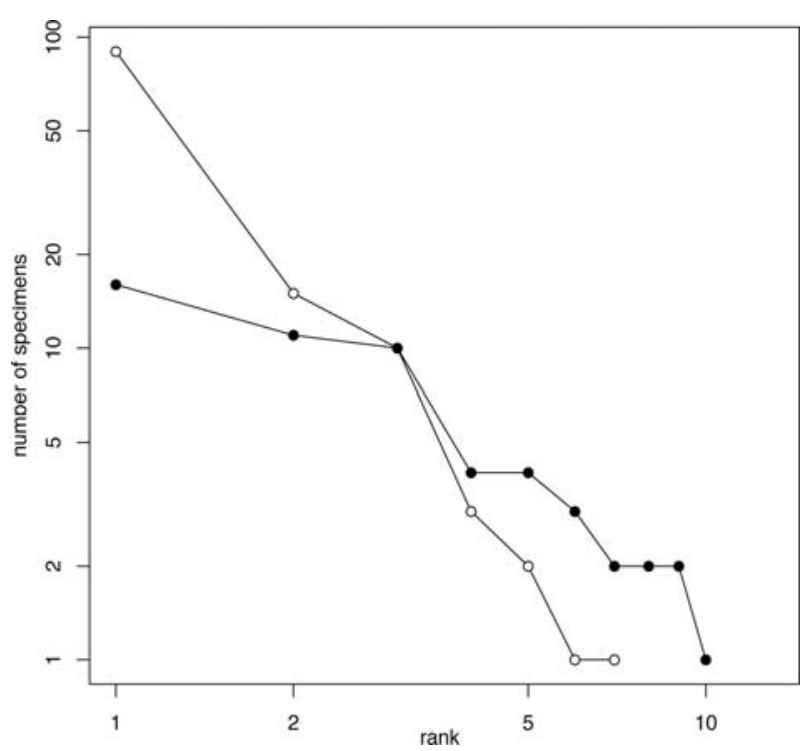

Figure 3. Abundance rank diagrams (log-log scale) of cephalopod species of the Lower Ordovician of the Montagne Noire. Black dots: Species of the St. Chinian Formation, latest Tremadocian. The three most abundant species are Bactroceras mourguesi (Thoral, 1935), Lobocyclendoceras undulatum n. sp., and Saloceras chinianense (Thoral, 1935); White dots: Species of the La Maurerie Formation, earliest Floian. The three most abundant species are Saloceras chinianense (Thoral, 1935), Rioceras escandei (Thoral, 1935), and Bactroceras mourguesi (Thoral, 1935) (see Table 1 for data, without specimens from St. Chinian).

the St. Chinian Formation, allowing a rate of immigration combined with good substrate conditions for benthic groups. The dominant cephalopods of the St. Chinian Formation are slender orthocones with thin tubular, or nearly tubular siphuncles, similar or congeneric to forms which are often concentrated in deep depositional settings or black shale sediments, and which are interpreted as open water, pelagic vertical migrants (Kröger et al. 2009). Their occurrence in the relatively deep-water sediments of the St. Chinian Formation supports this interpretation, as do examples such as that of the Dapingian Pontyfenni Formation of South Wales, where although somewhat younger, a range of trilobite taxa including agnostids and cyclopygids (Fortey \& Owens 1987) occur, together with a diverse assemblage of styloporans (Jefferies in Fortey \& Owens 1987), combined with the rare occurrence of Bactroceras (Evans 2005). On the basis of such observations, the cephalopod assemblage is interpreted as being parautochthonous in origin.

\section{La Maurerie Formation}

The boundary between the La Maurerie Formation and the underlying St. Chinian Formation is gradational, and develops into a succession consisting of an alternation of sandstones and shales bearing centimetric scale siliceous nodules, and reaches a thickness estimated to be greater than $900 \mathrm{~m}$ (Vizcaïno et al. 2001). The tran- sition from the St. Chinian to the La Maurerie Formation is interpreted as a shallowing upward sequence, and the La Maurerie Formation has been referred to as progradational (Vizcaïno et al. 2001). In a sedimentological study of the Floian successions in the Roquebrun area of the eastern Montagne Noire, Noffke \& Nitsch (1994) interpreted the depositional environment of the La Maurerie Formation as outer shelf muds combined with distal and proximal tempestites.

The high diversity of echinoderms and trilobites of the St. Chinian Formation diminishes in the La Maurerie Formation (Vizcaïno et al. 2001), although, in general, the trilobite fauna appears to be more abundant. This is largely accounted for by the extreme abundance of the index fossil of faunizones $\mathrm{G}$ and $\mathrm{H}$, Taihungshania miqueli (Bergeron). Cephalopods are less diverse than in the St. Chinian Formation (Tab. 1). The evenness of the association is very low, Saloceras Evans, 2005 is by far the most common genus (Tab. 1, Fig. 3). The cephalopod association consists exclusively of slender orthocones belonging to the families Baltoceratidae, Eothinoceratidae, Rioceratidae fam. nov. and Troedssonellidae. Remarkable is the lack of endoceridans, which are common in the St. Chinian Formation.

\section{Preservation and taphonomy}

The present investigation is based entirely on previously collected material, all of which appears to be preserved in concretions, and is now held in museum collections. Such samples could be biased as fossils are also preserved in the surrounding sediments (Dean 1966), but as indicated by Thoral (1946) the specimens in the concretions are of greater importance, as they are the only specimens that are in a good state of preservation. The case is emphasized for cephalopods where flattened and deformed material is typically difficult to interpret in terms of its taphonomic history, which often creates impediments to resolving aspects of the taxonomy of the assemblage. Thoral (1946) also emphasized the range of different concretions and styles of fossil preservation associated with them.

As for the most part, the precise horizons from which the concretions were collected are not known it is not possible to draw any inferences with regard to geographical or stratigraphical variations in modes of preservation. Nevertheless, the cephalopods preserved in different concretions exhibit different modes of preservation indicating that a variety of taphonomic histories are implicated.

It is clear from Thoral's (1946) descriptions of the concretions, as well as our own observations, that although in most specimens the original shell was dissolved, leaving only internal and external moulds of various elements of the phragmocone and body-chamber, some replacement of shell materials has also taken place. A detailed investigation of this aspect of the pre- 


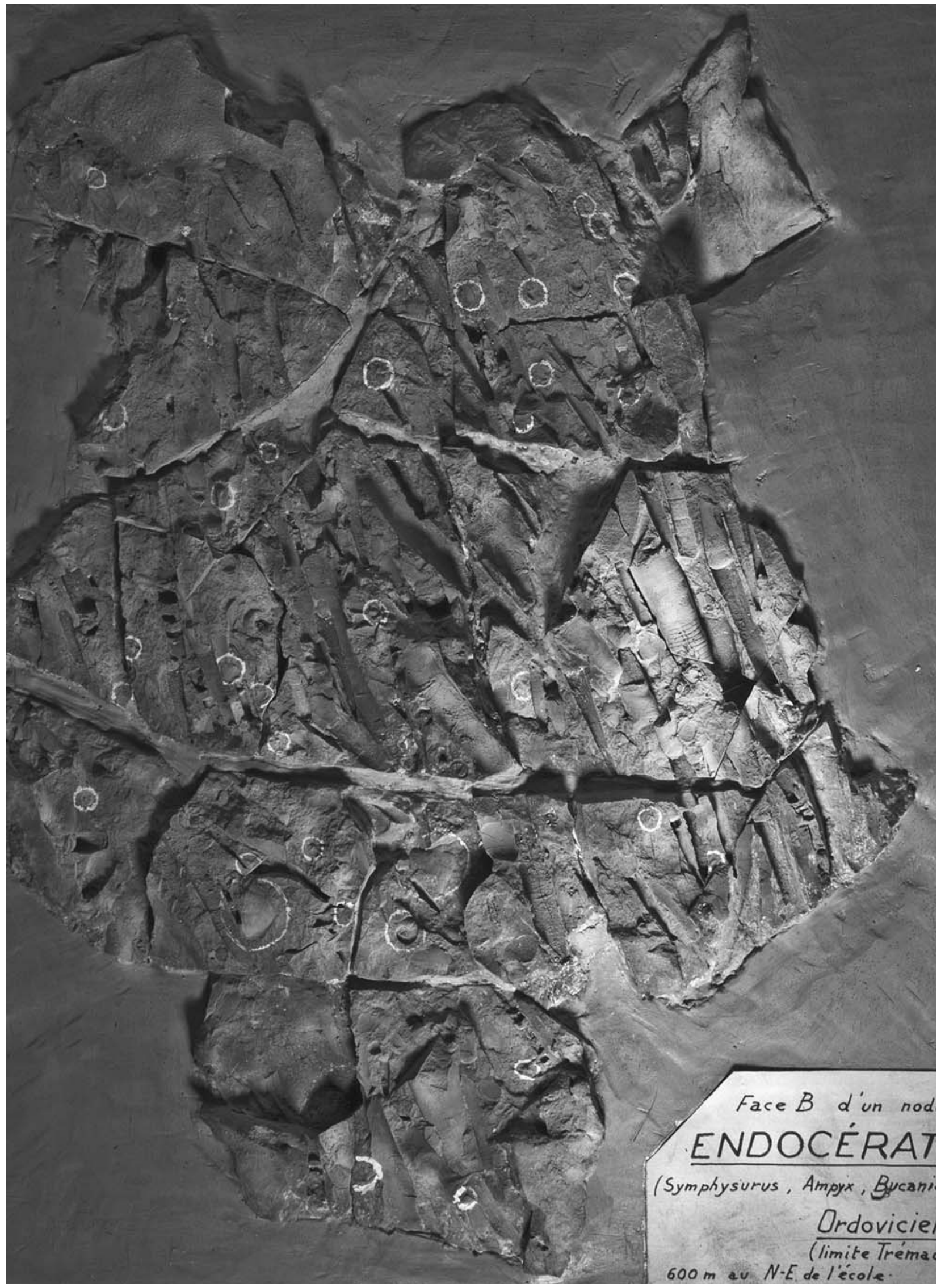

Figure 4. Large concretion from La Maurerie Formation, Prades-sur-Vernazobres (FSL 392293) with common Rioceras escandei, and Bactroceras mourguesi and a strong unimodal, parallel-aligned orientation. See text for discussion. $\times 0.2$. 
servation of the cephalopods in the concretions is, however, beyond the scope of this work.

In general the moulds within the concretions are in an undeformed or only slightly deformed state. A minority of concretions contain moulds that are slightly compressed. This suggests that for the most part, the development of the cement in the concretions was an early diagenetic event and they had been fully lithified before any significant burial had taken place.

Several modes of preservation of the shells are indicated by the condition of the moulds. In the large concretion from the La Maurerie Formation, Prades-surVernazobres (FSL 392293, Fig. 4; see also Thoral 1935, pl. 17, fig. 1) the moulds of the shells, which are not deformed, represent more complete specimens. In these specimens the preserved remains consist of an adoral portion of the shell where the camerae are infilled with sediment combined with a siphuncle that may be sediment-filled throughout the preserved length of the specimen. The apical end of the shell may consist of the external mould of the phragmocone and the mould of the siphuncle, all other parts having been lost to dissolution. A strong unimodal, parallel-aligned orientation is evident in the concretion and the majority of apices point in the same direction.

The incomplete sediment infill of those parts of the shell closest to the aperture suggests rapid burial and their lack of deformation indicates rapid lithification, probably similar to a generalized model developed by Loi \& Dabard (2002, fig. 13). The near unimodal orientation of the specimens in this concretion is similar to pattern of Silurian cephalopod limestones of the Mojerokan Formation, Llandovery, Siberia (Bogolepova 1995; Bogolepova \& Holland 1995) and to the Braník Type cephalopod limestone (Ferretti \& Křiž 1995), which are interpreted as deposited under relative gentle currents under the influence of upwelling zones (Bogolepova 1998).

Features, similar as in concretion FSL 392293 also have been reported by Radley (2008) from the Early Jurassic Blue Lias Formation of central England where densely packed concentrations of schlotheimiid ammonites occur in pipe-like concretions that he interpreted as scour fills and gutter casts and attributed to low velocity distal storm flow below storm wave base. The ammonites are strongly imbricated and the inner whorls partially crushed, suggesting that sediment only penetrated the body-chambers and adoral camerae. The similarities between the two occurrences invite interpretation of the Prades-sur-Vernazobres concretion, FSL 392293, as having originated as a gutter cast formed by a distal storm generated current below storm wave-base.

Such an interpretation is supported by the taxonomic composition of the concretion FSL 392293, which is dominated by Rioceras escandei (Thoral, 1935), followed by Bactroceras mourguesi (Thoral, 1935), and is in marked contrast to the taxonomic composition of the total cephalopod assemblage of the La Maurerie Formation (based upon the University of Lyon collections) which is dominated by Saloceras chinianense (Thoral,
1935) (Tab. 1, Fig. 3). R. escandei and B. mourguesi are two of the taxa that occur in the deeper water settings of the St. Chinian Formation. Both taxa are also characterized by low apical angles and narrow siphuncles; features indicative of a high level of resistance to elevated hydrostatic pressures (Westermann 1977, 1998) and are potential pelagic forms. The assemblage associated with the Prades-sur-Vernazobres concretion FSL 392293 therefore indicates a faunal composition of deeper or more open water conditions compared with that of the average La Maurerie Formation.

In other concretions of the St. Chinian and La Maurerie formations often the most aperturally placed camerae and/or the body chambers of the conchs are infilled with sediment and appear to have been preferentially preserved. In many of the specimens in these concretions part of the siphuncular mould may be preserved with no traces of the chambers or phragmocone wall remaining. This type of preservation may be interpreted as a result of conch implosion during sinking of the dead shells, which often destroys the more adapical conch parts (Hewitt \& Westermann 1996). Direct evidence of conch buckling and septal fragmentation is absent in the material. This may be a result of an implosion of the conchs already in the water column and a separate deposition of the adapertural and apical parts of the imploded shell. A similar taphonomic scenario was illustrated by Hewitt \& Westermann (1996, fig. 8, scenario 2b) for Ordovician and Silurian orthocone dominated environments.

The majority of cephalopod shells present in the St. Chinian and La Maurerie formations grew to less than $20 \mathrm{~mm}$ in diameter. As small cephalopod conchs are considered to have the least potential for extensive post-mortem drifting (Wani et al. 2005) the drifting distances are estimated as relatively short. Westermann (1985) and Hewitt \& Westermann (1996) analyzed the post-mortem drifting behaviour of nautiloids and came to the conclusion that ,the majority of the Lower Paleozoic nautiloids were unlikely to have drifted unless their body-chambers were removed by predators" (Hewitt \& Westermann 1996, 412). Because the conchs of the of the St. Chinian and La Maurerie formations often consist of the adapertural parts and parts of the body-chamber, we conclude, that the majority of the cephalopod association in the nodules reflects the composition of the fauna associated with the sea floor and water column above. However, the concretion FSL 392293 testifies the presence of currents and transport of the dead shells at least in some events during the deposition of the La Maurerie Formation.

\section{Synopsis - Faunal composition and depositional setting}

The cephalopods of the St. Chinian and La Maurerie Formation are interpreted as generally parautochthonous, representing a fauna which originally predomi- 
nantly lived in the open water above the sediments or related to the sea bottom. The small average size of the specimens is interpreted as evidence against long drifting distances. The conchs are interpreted as fragments of imploded shells. The frequent preservation of fragments of body-chamber and adjacent adapertural phragmocone-chambers supports our interpretation of short drifting distances.

The rich benthos of the comparatively deep depositional environment of the St. Chinian Formation is accompanied by a rich association of cephalopods, consisting predominantly of orthoconic cephalopods. Because most of the conch are interpreted as fragments of imploded shells, the majority of orthocones, specifically the baltocerids, in the St. Chinian Formation are interpreted as pelagic forms, which lived in the open water above the sea bottom and imploded during sinking. The high diversity, evenness and abundance of both benthic and nektonic faunal elements in the St. Chinian Formation indicates episodes of good life conditions at the bottom and in the water column in the generally poorly oxygenated depositional environment, probably in an upwelling zone.

By contrast, the shallower, more sandy depositional environments of the La Maurerie Formation contain a less rich benthos and a less diverse assemblages of cephalopods, indicative for more restricted habitats. The dominance in abundance of the eothinoceratid Saloceras Evans, 2005 may be related to the high abundance of asaphids, specifically, to the acme of T. miqueli. A single large concretion with concentrations of Rioceras escandei (Thoral, 1935), and Bactroceras Holm, 1898 indicates the additional presence of storm deposits with conchs transported from more offshore. Differences in general faunal composition between the St. Chinian Formation, and the La Maurerie Formation are interpreted as related to the depositional depth.

\section{Comparison with contemporaneous cephalopod associations elsewhere}

The composition of the Montagne Noire associations contrast markedly with the late Tremadocian cephalopod associations known from low latitude carbonate platforms. With the possible exception of the breviconic Cyclostomiceras Hyatt in Zittel, 1900, the cephalopod fauna of the St. Chinian and La Maurerie Formation consists exclusively of slender orthoconic shells. The baltocerid Bactroceras Holm, 1898 is the most abundant cephalopod in the Tremadocian St. Chinian Formation. However, richness and evenness of the St. Chinian Formation assemblages are not lower than compared with the low latitude carbonate platform assemblages of New York (Tab. 1). The cephalopod assemblages of low latitude carbonate platforms are often strongly dominated by endocerids (Hunghuayuan Formation, Hubei, China [Xu \& Lai 1987]; Jefferson City Dolomite, Missouri,
USA [Ulrich et al. 1944]; Liangchiashan Formation, Hebei, China [Lai 1985]; Santao Formation, North China [Endo 1932]). In the Jefferson City Dolomite, bassleroceratids and tarphycerids are also common elements of the cephalopod assemblage. One of the few genera that appears to be common to to the high and low latitude assemblages is the orthoconic ellesmerocerid Rioceras which was first described from the Stairsian of the southwestern United States (Flower 1964) where it ranges upwards into the Blackhillsian. It is noteworthy that of the North China faunas, Rioceras was also described from the Liangchiashan Formation, Hebei, China, by Lai (1985), whilst a specimen attributed to the orthocerid Kyminoceras Teichert \& Glenister, 1954, was described by Chen (1976). Several eothinocerids were also described from the Liangchiashan Formation by Lai (1985) and Chen \& Teichert (1987).

The early-mid Floian (TS 2a-b, IGCP 410 Time Slices of Webby et al. 2004) cephalopod faunas of the low paleo-latitude carbonate platforms exhibit a different picture. Although endocerids and tarphycerids predominate within these assemblages, protocycloceratids and troedssonellids are not an uncommon component of the fauna. This is demonstrated by many of the faunal lists of cephalopods from the Appalachians, New York, Quebec and Newfoundland compiled by Ulrich et al. (1944) as well as by more recent studies of the Fort Cassin Formation, New York (Kröger \& Landing 2009) and the Durness Group of northwest Scotland (Evans in preparation). In terms of relative abundance, troedssonellids appear to become increasingly common towards Newfoundland and northwest Scotland.

The trend of increasing abundance of orthocerid, protocycloceratid and troedssonellid cephalopods in Laurentian platform carbonates continues during the later Floian in several Laurentian associations (Flower 1962; Hook \& Flower 1977). Such a trend is unknown in the late Floian deposits of North China (Machiakou, and Sandaokan formations, e.g. Chen \& Zou 1984) that are characterized by a unique fauna of endocerids associated with some of the earlier actinocerids. The causes of the increasing abundance of orthoceroids in the low latitude platform carbonates, especially in Laurentia have yet to be understood, but a paleogeographical and palaeobathymetric trend has become more apparent, suggesting an origin and initial expansion of orthoceroid-like forms in high latitudes and deeper water settings.

Tremadocian cephalopod associations consisting exclusively or predominantly of orthocerids and orthocerid-like orthocones are initially confined to high latitudinal occurrences. Only three such occurrences of orthoceroids are known, and one of these is ambiguous. Slemmestadoceras attavus (Brøgger, 1882) occurs with an as yet undescribed Ellesmeroceras Foerste, 1921 in the middle Tremadocian Bjørkåsholmen Formation in Norway (Kröger 2008), and the middle Tremadocian collection from the Rio Salinas Member, Tiñu Formation of Oaxaca State, Mexico, which is dominated by 
Rioceras and as yet undescribed eothinoceratids (Flower 1968; Landing et al. 2007). Wilson (1954) reported indeterminate baltoceratids from olistostrome boulders of probable Tremadocian age in the Middle to Upper Ordovician Woods Hollow Formation of Texas. To these few Tremadocian occurrences can be added the occurrence of Annbactroceras martyi (Thoral, 1935), Bactroceras mourguesi (Thoral, 1935), and Rioceras estivali (Thoral, 1935) from the St. Chinian Formation, reported herein. With the exception of those from the boulders of the Woods Hollow Formation, all these occurrences are from relatively deep-water depositional environments of the high latitudes.

Early Floian cephalopod associations containing exclusively or predominantly orthoceratoids are rare. The assemblage of the Floian La Maurerie Formation is in which Bactroceras Holm, 1898 is relatively common, but which is dominated by the eothinoceratid Saloceras Evans, 2005 is not an exception. The cephalopod faunas of the early Floian (TS 2a, IGCP 410 Time Slices of Webby et al. 2004), Bolahaul Member, Ogof Hên Formation and Henllan Ash Member, Carned Iago Formation, of Wales, earliest Floian (TS 2a) are similar to those of the La Maurerie Formation in that Saloceras is the most common genus. In Wales, the accompanying genera consist of the polymeriid Polymeres Evans, 2005, the troedssonellid Moridunoceras Evans, 2005, and the baltoceratid Castelloceras Evans, 2005, whilst the possible orthocerid Semiannuloceras Evans, 2005 (see Kröger 2008 for discussion of relationships) first occurs in slightly younger Floian sediments deposited in deeper-water facies (Fortey \& Owens 1987). From Bolivia, Marek et al. (2000) reported Bactroceras aff. avus Holm, 1898, and Bathmoceras Barrande, 1867, from strata yielding also endocerids and ellesmerocerids in carbonate nodules present in dark siltstones of early Floian age.

The available data suggest an initial expansion of orthoceroid cephalopod faunas from open water habitats of high paleo-latitudes, and a subsequent expansion on the carbonate platforms during the Floian. The occurrences in the St. Chinian, and La Maurerie formations, reported herein, support this interpretation.

In conclusion, it is evident that the cephalopod associations of the St. Chinian and La Maurerie formations are similar to other contemporaneous assemblages known from higher paleo-latitudes and associated with deeper depositional settings. They are composed almost exclusively of longiconic orthocones, in this case predominantly of eothinoceratids and Bactroceras. The occurrence of Annbactroceras, and Bactroceras in the St. Chinian Formation are at present the earliest unambiguous reports of the Orthocerida. The orthocerid and orthocerid-like elements of the Montagne Noire assemblages, and from other comparable late Tremadocianearly Floian high latitude settings become increasingly common and widespread on low latitude carbonate platforms during the Floian.

\section{Paleogeographic relationships}

As already outlined above, the early Ordovician cephalopod fauna of the Montagne Noire is quite distinct from faunas that were present at lower latitudes, not only in their morphological diversity but also in their taxonomic diversity. High latitude cephalopod faunas of this age remain relatively poorly known, although several recent studies and partial revisions of assemblages have improved our knowledge of these faunas. Furthermore, the location of the Montagne Noire on the margin of Gondwana would suggest that the cephalopod fauna might show some connections with Gondwanan low latitude assemblages.

Early Ordovician cephalopod faunas were described from the Argentine Precordillera by Aceñolaza et al. (1977), Aceñolaza \& Beresi (2002) whilst Kröger et al. (2007) specifically described the faunas from the upper part of the San Juan Formation, of late Floian and early Dapingian age which was dominated by orthocerids. These included some of the material described by Aceñolaza \& Beresi (2002). The older (late Tremadoc and early Floian) part of the assemblage from the San Juan Formation described by Aceñolaza et al. (1977), Aceñolaza \& Beresi (2002) is in need of revision, but includes representatives of the Tarphycerida and Piloceratidae as well as possible ellesmeroceratids. The composition of this assemblage clearly reflects its low latitude Laurentian provenance of the Precordillera terrane (Astini 2003) and contrasts strongly with the Tremadoc and Floian cephalopod assemblages recorded from the Central Andean Basin. Cecioni (1953, 1965) described a number of species of cephalopods from the late Tremadoc and Floian of the Purmamarca area of Jujuy Province and from the Rio Las Capillas, northeast of San Salvador De Jujuy. Unfortunately, many of the figures of specimens described by Cecioni are difficult to interpret, and partly as a consequence of this, these faunas are in need of revision. What is clear is that the assemblage consists almost entirely of orthoconic or very slightly cyrtoconic longicones, with a few taxa (Cyclostomiceras, Paracyclostomiceras Cecioni, 1965 and Clarkeoceras argentinum Cecioni, 1965) having a more breviconic form. Cyclostomiceras depressius (Cecioni, 1965) requires revision, but suggests the presence of at least one genus common to the Montagne Noire. Several annulate forms were assigned to species of Protocycloceras Hyatt in Zittel, 1900, whilst a number of other smooth forms with large marginal siphuncles were assigned to Baltoceras (= Cochlioceras Eichwald, 1860). Of the taxa assigned to Cochlioceras there appears to be some variability in cameral depth, whilst the diameters of the siphuncles are somewhat greater than those known from the type species C. avus Eichwald, 1860 or other species including C. burchardi Dewitz, 1879 and C. roemeri Dzik, 1984 and for most of the taxa erected by Cecioni, the camerae are more shallow. Evans (2007) noted the possible presence of the 
Eothinoceratidae based upon a specimen figured by Harrington (1937: 110, pl. 7, fig. 11) from the late Tremadocian Parcha Formation of Incamayo, Salta Province. Cichowolski et al. (2010) have confirmed the presence of the Eothinoceratidae in Argentina by describing Saloceras cf. sericeum from mid Tremadocian horizons of the Floresta Formation, Salta Province. The detailed revision of Protocyptendoceras Cecioni, 1965 by Cichowolski (2009) now facilitates comparison with other members of the Proterocameroceratidae, and it is suggested below that this genus is very closely related to Lobendoceras Teichert \& Glenister, 1954. Whilst the Tremadoc and early Floian cephalopods of the Argentine sector of the Central Andean Basin require revision, what is known of them suggests that they have some affinity with those of the Montagne Noire.

As noted above, the Tremadocian Tinu Formation of Oaxaca State, Mexico, contains Rioceras and undescribed eothinoceratids. The earliest eothinoceratids are known from bed $\mathrm{Tu}-35.9$ in the dark shales of the Rio Salinas Member, Tiñu Formation (Paltodus deltifer Conodont Zone), Oaxaca, Mexico (Landing et al. 2007). The southern part of Mexico has been demonstrated on biostratigraphical and lithostratigraphical evidence to belong to the Gondwana margin (Landing et al. 2007).

The late Tremadocian and early Floian cephalopods of Avalonia as represented by the assemblages of England and Wales (Evans 2005) differ from those of the Montagne Noire in the presence of Saloceras sericeum (Salter in Ramsay, 1866) rather than the forms described below from the La Maurerie Formation. Other differences between the assemblages include the relatively low diversity of the English and Welsh faunas by comparison with those of the Montagne Noire, the extreme dominance of Saloceras $(92 \%$ of the cephalopods $[n=631]$ in the early Floian Bola Haul Member of the Ogof Hên Formation, South Wales [Evans 1988]), and the presence of the orthoceratoids Polymeres Murchison, 1839 and Moridunoceras Evans, 2005 which unlike most orthoceratoid taxa from the Montagne Noire possess well-developed endosiphuncular and cameral deposits. Whilst the English and Welsh faunas do have Saloceras in common with the Montagne Noire faunas, other differences in diversity and composition suggest that there was some degree of separation (distance or physical barrier) between the two assemblages.

The geographical and stratigraphical distribution of the Ordovician cephalopod faunas of Australia were reviewed by Webby et al. (2000) who observed that cephalopods of Lower Ordovician age were present in most of the Australian sedimentary basins (Percival in Webby et al. 2000, fig. 4), but that the faunas were either incompletely researched, dated relatively imprecisely, or their precise stratigraphical horizons were poorly resolved. With those caveats in mind, Webby et al. (2000) summarized the faunal relationships between the different basins as sharing few species, although there were more genera in common. In particular he noted the similarity between the assemblages of the Amadeus, Georgina, and Wiso Basins, the Tas- manian Shelf, and those of the Sibumasa Block and North China. It should be noted, however, that most of these assemblages are younger (late Floian to early Darriwilian) than those of the Montagne Noire.

The only late Tremadoc to early Floian cephalopod assemblage currently known from Australia was described (Teichert \& Glenister 1954) from the Emanuel Limestone of the Canning Basin, Western Australia. This morphologically very diverse early Floian cephalopod association is composed of ellesmerocerids, endocerids, tarphycerids, early oncocerids and the possible discosorid Apocrinoceras talboti Teichert \& Glenister, 1954. The although several taxa appear to be either endemic to the Canning Basin or Australia, others, in particular some of the tarphycerids clearly belie the low latitude provenance of the fauna, whilst some of the genera (Hardmanoceras Teichert \& Glenister, 1952, Thylacoceras Teichert \& Glenister, 1952) indicate some affinity with the Sibumasa Block and North China. The Emanuel Limestone also contains taxa that suggest links with higher latitude cephalopod assemblages. Whilst Eothinoceras Ulrich et al., 1944 may be widely distributed across low latitude carbonate platforms during the late Tremadoc and early Floian; the genus having first been described from the Rochdale Limestone of New York (Ulrich et al. 1944; Kröger \& Landing 2008), then from the Canning Basin (Teichert \& Glenister 1954), North China (Chen \& Teichert 1987) and Bolivia (Cecioni \& Flower 1985; Evans 2007). Evans (2005, 2007) suggested that Protocycloceras contrarium Teichert \& Glenister from the Emanuel Limestone might in fact be a Saloceras given the well-developed ventral saddle and remarkably thick connecting rings. The proterocameroceratid Lobendoceras Teichert \& Glenister, 1954 from the Emanuel Limestone is present in the La Maurerie Formation of the Montagne Noire, and possibly also in the Central Cordilleran Basin of Argentina. The orthocerid Kyminoceras Teichert \& Glenister, 1954 shares some similarities with Annbactroceras n. gen. herein in the possession of an annulate shell with a narrow siphuncle composed of orthochoanitic septal necks and thin, slightly convex connecting rings.

Tremadocian and early Floian cephalopod faunas from other regions that are considered to have been situated at a high latitude during the early Ordovician are either unknown (e.g. Perunica), consist of a single record (e.g. Cameroceras cf. vertebrale [Eichwald, 1860] in Gnoli \& Pillola [2002], [= Saloceras, see Evans 2005] from the Floian of Sardinia), or remain undescribed (e.g. Morocco [pers. comm. Bertrand Lefebvre 2009]; Iran [pers. comm. Leonid Popov 2009]).

\section{Conclusions}

The cephalopod fauna of the early Ordovician of the Montagne Noire is, by comparison with other high latitude Gondwanan faunas, taxonomically diverse. The 


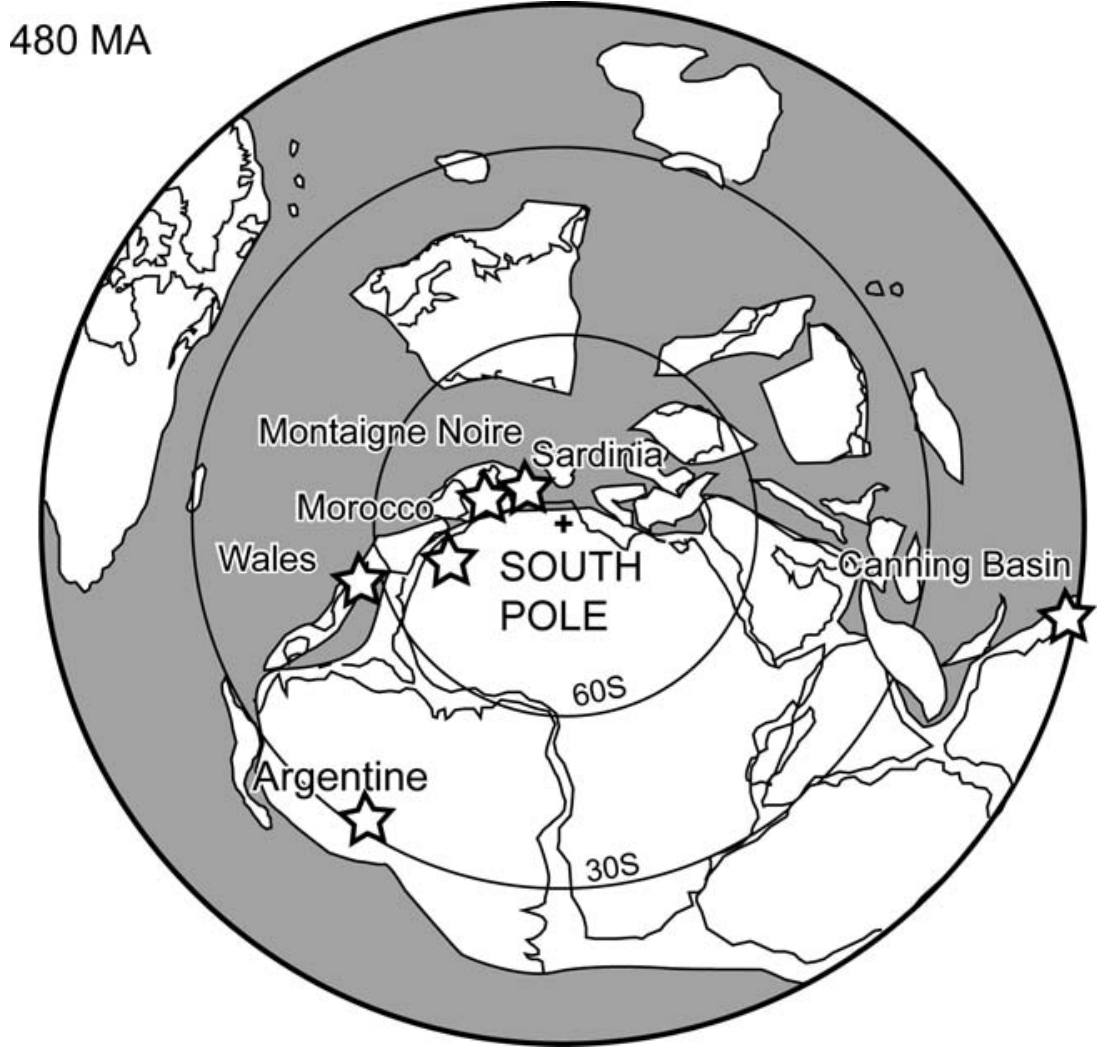

Figure 5. Palaeogeographical reconstruction of the southern hemisphere at late Tremadocian time. Stars mark occurrences of Saloceras Evans, 2005. Note the circum-Gondwana occurrences of this genus. presence of the eothinoceratid Saloceras in abundance demonstrates the Gondwanan affinity of the assemblage whilst adding further support for the presence of a 'Saloceras realm' that may have extended along the margins of East and West Gondwanan at least into intermediate latitudes (Fig. 5). The presence of the proterocameroceratid Lobendoceras may also support this contention.

The presence of unambiguous members of the Orthoceratoidea in the St Chinian Formation extends records of this group into the late Tremadocian. The increasing diversity and abundance of the Orthoceratoidea in the overlying La Maurerie Formation, combined with the evidence from the St Chinian Formation lends support for an initial distribution of at least part of the Orthoceratoidea at higher palaeolatitudes in open-water settings.

\section{Systematic Paleontology}

Class Cephalopoda Cuvier, 1797

Subclass Nautiloidea Agassiz, 1847

Order Ellesmerocerida Flower in Flower \& Kummel, 1950

Family Cyclostomiceratidae Foerste, 1925

\section{Genus Cyclostomiceras Hyatt in Zittel, 1900}

Type species. Gomphoceras cassinense Whitfield, 1886; by original designation.

Diagnosis. Very weakly cyrtoconic brevicones with a rapidly expanding phragmocone, and a body-chamber that is generally (but not in- variably) contracted adorally at maturity. Conch cross-section moderately compressed to moderately depressed. Aperture of body-chamber relatively wide and apparently lacking a hyponomic sinus. Shell ornamented with fine growth lines. Sutures nearly straight and almost directly transverse. Siphuncle small, ranging from 0.13 to 0.07 of phragmocone diameter and slightly submarginal in position. Septal necks short and nearly straight with connecting rings that range from thick and concave to thin and concave (after Ulrich et al. 1944, 55; King 1999, 339).

\section{Cyclostomiceras thorali n. sp.}

Figures $6 \mathrm{~A}-6 \mathrm{C}$

1935 Orthoceras indéterminés Type B. - Thoral, 195, pl. 16, fig. 2a-2b.

Derivation of name. In honour of Marcel Thoral (1900-1956) for his major palaeontological contributions on the Early Paleozoic fauna of the Montagne Noire.

Holotype. Specimen FSL 392081.

Type locality and horizon. St. Chinian Formation, Euloma filacovi Zone, late Tremadocian, from Félines-Minervois, Hérault, France.

Material. Holotype and one additional specimen, FSL 392082, from type horizon and locality.

Diagnosis. Small, essentially straight conchs reaching a maximum diameter $10 \mathrm{~mm}$ or less. Apical angle of phragmocone and adapical part of adult body chamber $15^{\circ}$. Adoral portion of body-chamber contracting very slightly adorally. Septal spacing narrow, with approximately 9 chambers in a distance equivalent to the conch cross section. Sutures straight, slightly inclined toward the aperture on dorsal side with a distinct v-shaped ventral saddle over the siphuncle. Siphuncle marginal with a diameter 0.14 of conch cross-section.

Description. The holotype consists of the internal mould of the last two chambers of the phragmocone and body chamber with a total length of $11 \mathrm{~mm}$. The 


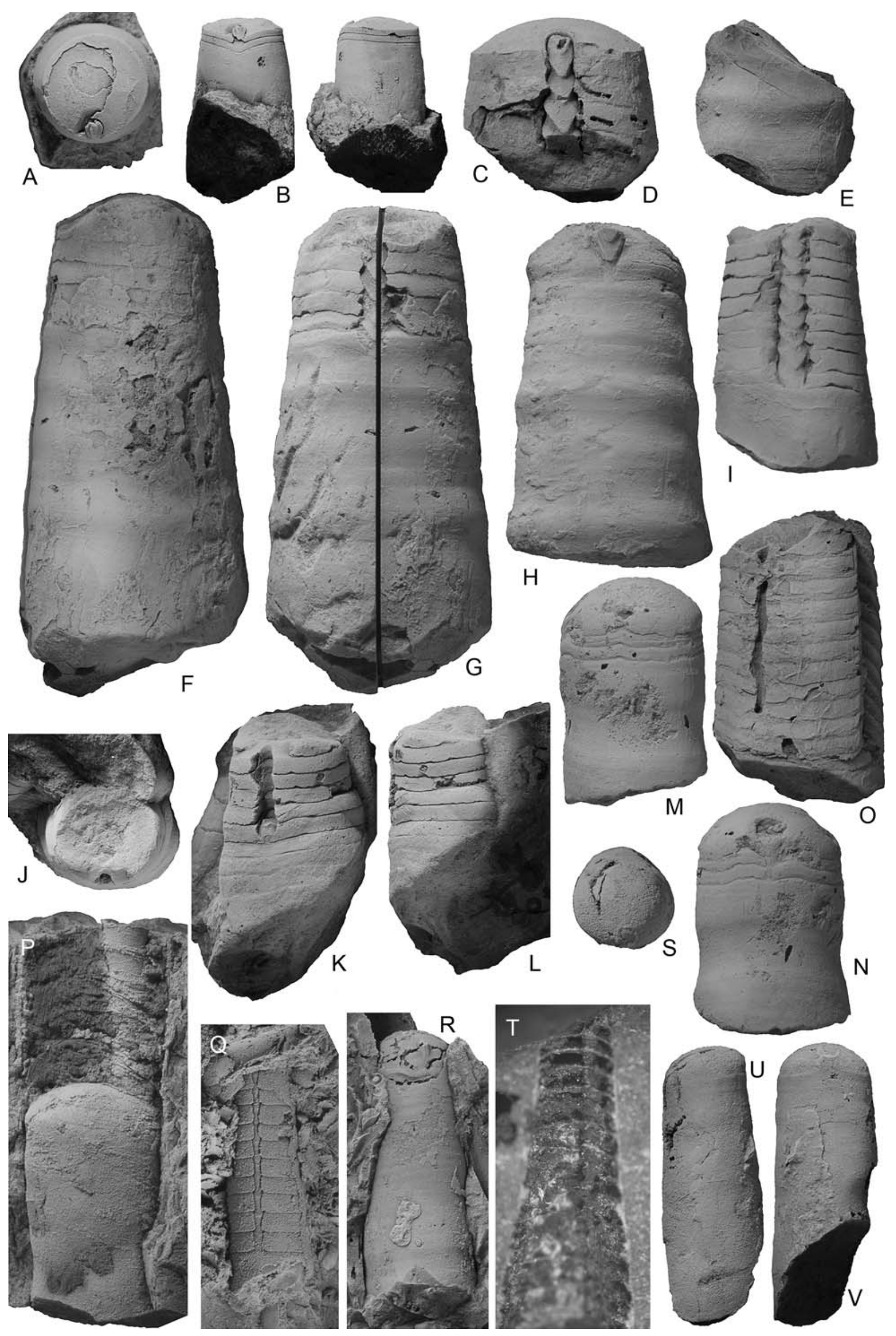


length of the preserved part of body chamber is $9 \mathrm{~mm}$. The conch cross-section is nearly circular but very slightly depressed with a dorsoventral diameter $9.1 \mathrm{~mm}$, and a lateral diameter of $9.2 \mathrm{~mm}$ at the base of the body-chamber. The body-chamber has diameter of $10 \mathrm{~mm}$, and $10.3 \mathrm{~mm}$ respectively $4 \mathrm{~mm}$ adorally of its base. The angle of expansion of the body-chamber decreases adorally so that it contracts slightly. The surface of the internal mould is essentially smooth. The sutures are $1 \mathrm{~mm}$ apart, giving a cameral depth 0.11 that of the phragmocone diameter. The sutures are slightly inclined towards the aperture on the dorsal side of the phragmocone and form distinct V-shaped ventral saddle with a height of $0.75 \mathrm{~mm}$ and width of $6 \mathrm{~mm}$ over the siphuncle. The siphuncle is marginal in position, circular in cross-section and $1 \mathrm{~mm}$ in diameter, or 0.11 of the phragmocone diameter. The siphuncular segments are concave and the connecting rings may have been thick.

The second specimen is a strongly deformed fragment consisting of five camerae and part of the bodychamber with a total length of $15 \mathrm{~mm}$. The sutures display the same distinctive ventral saddle as seen in the holotype (Fig. 6B).

Stratigraphic and geographic occurrences. Euloma filacovi Zone, St. Chinian Formation, late Tremadocian, Montagne Noire, Hérault.

Discussion. In terms of their cross-sections (8 and $10 \mathrm{~mm}$ ) and general shape, the specimens described and figured by Thoral (1935, pl. 16, figs $2 \mathrm{a}-2 \mathrm{~b}$ ) are nearly identical with the two specimens described above. Thoral (1935) considered the possibility, that these small specimens might represent fragments of juvenile individuals of Saloceras chinianense (Thoral,
1935), but the contraction towards the aperture of the body-chamber in Thoral's figured specimen and in the holotype indicates that these individuals reached maturity at a small size and so do not belong to S. chinianense.

In terms of its dorsoventral and lateral profiles, as well as overall size, $C$. thorali is closest to $C$. minimum (Whitfield, 1886), with which it also shares the nearly circular conch cross-section that is apparent in some representatives of the latter species (Ulrich et al. 1943, pl. 32, Figs 2, 3). However, the position, size and form of the siphuncle is different. Whilst $C$. thorali is similar to $C$. cassinense in terms of the size of the siphuncle and the thickness of the connecting rings, C. thorali differs in the marginal position of the siphuncle as well as the overall shape and size of the shell. C. thorali differs from all species of Paracyclostomiceras Cecioni in that in Paracyclostomiceras the maximum diameter of the shell occurs on the phragmocone rather than on the body-chamber, whilst the sutures show well developed lateral lobes and dorsal and ventral saddles, although the siphuncle is of a similar size and position to that of C. thorali. C. thorali differs from Pictetoceras Foerste, 1926 in much the same way as it differs from Paracyclostomiceras, although the siphuncle in Pictetoceras is somewhat larger.

Family Eothinoceratidae Ulrich, Foerste, Miller \& Unklesbay, 1944

\section{Genus Saloceras Evans, 2005}

Type species. Orthoceras sericeum Salter in Ramsay, 1866; by original designation.

Figure 6. Ellesmerocerida of the Early Ordovician of the Montagne Noire. A-C. Cyclostomiceras thorali n. sp. FSL 392081, St. Chinian Formation, Félines-Minervois, Hérault; A. Septal view of adoral end of phragmocone showing the septal foramen, venter down. $\times 1.0$; B. Ventral view of body-chamber and adoral portion of phragmocone, $\times 1.5$; C. Lateral view of body-chamber and adoral portion of body-chamber. $\times 1.5$; D-I, O. Saloceras chinianense (Thoral, 1935). St. Chinian and La Maurerie formations; D. Ventral view of part of phragmocone showing intenal mould of siphuncle with deeply concave segments. FSL $392031 . \times 1.25$. Félines-Minervois, Hérault; E. Portion of strongly annulate body-chamber. FSL 392221. × 1.0. Prades-sur-Vernazobres, Canto Cigale, Hérault; F-G. FSL392074. St. Chinian; F. Lateral view of body-chamber and part of phragmocone of moderately annulate shell, venter on left. $\times 1.0$; G. Ventral view of body-chamber and phragmocone, showing trace of siphuncle. $\times 1.0$. Environs de St. Chinian; H. Ventral view of body-chamber and part of phragmocone, showing irregular annulations. FSL 392058. Prades-sur-Vernazobre, Canto Cigale, Hérault. $\times 1.25$; I. Ventral view of phragmocone and part of body-chamber lacking annulations and showing a siphuncle with deeply concave segments. FSL 392230. Prades-sur-Vernazobre, La Maurerie, Canto Cigale, Hérault. $\times 1.25$; O. Lateral view of phragmocone lacking annulations (venter on right) and showing siphuncle with deeply concave segments. FSL 392079. St. Chinian. $\times 1.0$; J-L. Saloceras murvielense n. sp. FSL 392035. St. Chinian Formation, Félines-Minervois, Hérault; J. Septal view of phragmocone showing septal foramen (venter down). $\times 1.5$. Félines-Minervois, Hérault; K. Slightly oblique ventral view of annulate phragmocone and body-chamber. $\times 1.5$; L. Lateral view of phragmocone and body-chamber (venter on left). $\times 1.5$; M-N. Saloceras pradense (Thoral, 1935). FSL 392032. La Maurerie Formation. St. Chinian; M. Lateral view (venter left) of body-chamber and portion of phragmocone shown a constriction on the body-chamber. $\times 1.25$; N. Ventral view of phragmocone and body-chamber. $\times 1.25$; P-V. Rioceras escandei (Thoral, 1935). La Maurerie Formation; P. Body-chamber and part of phragmocone showing marginal siphuncle with slightly concave segments. FSL 392187. Prades-sur-Vernazobre, Canto Cigale, Hérault. $\times 2.0$; Q. Ventral view of phragmocone showing trace of marginal siphuncle on venter; FSL 392207. Félines-Minervois, Hérault. $\times 2.5$; R. Ventral view of body. chamber showing constriction on internal mould near aperture. FSL 392253. Félines-Minervois, Hérault. $\times 1.5$; T. Adventious section through siphuncle showing empty camerae and partially silicified septa and siphuncle. FSL 392193. Prades-sur-Vernazobre, Canto Cigale, Hérault. $\times 10 ;$ S, U-V. FSL 392289. Félines-Minervois, Hérault; S. Septal view of body-chamber showing septal foramen. $\times 2.0$; U. Lateral view of body-chamber (venter on right). $\times 2.0$; V. Ventral view of bodychamber. $\times 2.0$. 
Diagnosis. Orthoconic eothinoceratids with circular to slightly depressed cross section and moderate angle of expansion; sutures straight and directly transverse with ventral saddle over siphuncle; siphuncle marginal with diameter $0.3-0.5$ of corresponding phragmocone cross-section; septal necks achoanitic to weakly orthochoanitic; siphuncular segments strongly concave with connecting rings thickened, protruding into the siphuncle; siphonal diaphragms present. (Compiled from Evans 2005)

\section{Saloceras chinianense (Thoral, 1935)}

Figures 6E-I, $6 \mathrm{O}$

1935 Orthoceras chinianense Thoral: 182, pl. 15, figs $8 \mathrm{a}-8 \mathrm{~b}$, pl. 16, figs $5 \mathrm{a}-5 \mathrm{~b}$

1935 Orthoceras (Ellesmeroceras) estivali Thoral: 187, pl. 15, figs $6 \mathrm{a}-6 \mathrm{~b}$.

1935 Orthoceras Type C - Thoral: 195, pl. 15. figs 7a-7b.

Lectotype. USTM-ACI 412, figured by Thoral (1935, pl. 15, figs $8 \mathrm{a}-8 \mathrm{~b}$ )

Paralectotype. USTM-ACI 421, figured by Thoral (1935, pl.16, figs $5 \mathrm{a}-5 \mathrm{~b})$

Type locality and horizon. Basal Faunizone $\mathrm{H}=$ Taihungshania miqueli acme Subzone, of the La Maurerie Formation, earliest Floian, north of Assignan, Hérault, France.

Material. A total number of 120 specimens; 71 specimens (FSL 392038, 392046, 392050-392053, 392060, 392084-392088, $392104-392125$, 392138-392170, 392184-392185, 392221) from Prades-sur-Vernazobres, Canto Cigale; 11 specimens (FSL 392062392066, 392094-392099) from Assignan, La Cabosse; 10 specimens (392031, 392036, 392040-392045, 392059, 392083, 392131) from Félines-Minervois, 8 specimens (392089-392092, 392100-392103) from La Maurerie, Prades-sur-Vernazobres, and 21 specimens (392033, 392034, 392039, 392057, 392058, 392061, 392067-392080, 392134) from St. Chinian and surrounding area, all Hérault, France.

Diagnosis. Annulate Saloceras with a slight exogastric curvature, expanding at a rate of $10^{\circ}$; conch cross-section circular to weakly depressed; annulations weakly developed in earlier growth stages, but more pronounced later; distance between subsequent crests of annulations approximately 0.3 of conch cross-section diameter; three camerae occur per annulation and approximately 8 camerae in length similar to phragmocone diameter; sutures form weak lateral saddles combined with broad dorsal and ventral lobes, and a narrow but pronounced saddle over the siphuncle; siphuncle marginal, diameter 0.19 that of phragmocone; siphuncular segments strongly concave and thick; shape of septal necks not known.

Description. The shell possesses a slight exogastric curvature as seen in FSL 392074 (Fig. 6F). The rate of expansion of the conch varies between $7-11^{\circ}$ (1st and 3rd quartile, $n=28$ ) and there is little evidence for any consistent change in expansion rate with growth. The cross-section of the shell ranges from circular (FSL 392078) to elliptical and depressed with a dorsoventral diameter 0.81 that of the lateral diameter (FSL 392083). The annulations are very weakly developed or missing in juvenile parts of the shell, but become apparent and more pronounced at conch diameters greater than $20 \mathrm{~mm}$. Both the crests and troughs of the annulations are relatively gentle, and while they are almost transverse, they slope slightly toward the aperture on the dorsal side forming a shallow salient over the dorsum. The annulations may generally increase slightly in wavelength and amplitude with the diameter of the conch, but this is not regular and the correlation with conch diameter is very poor. The surface of the conch is either smooth, or with faint irregular growth lines.

The depth of the septa ranges from 0.08 to 0.2 (mean $0.12, n=28$ ) of the diameter of the phragmocone, but shows no obvious trend or correlation with increasing conch diameter. This may be a consequence of deformation, or might represent real variation in septal depth. In the specimens measured, cameral depth ranges from about 0.07 to 0.18 of the phragmocone diameter, and whilst there is no apparent trend in the change in cameral depth with diameter, the lower limit of the range may include increasingly shallow camerae as the diameter increases. FSL 392031 and FSL 392033 are typical in showing the sutures to be almost transverse, whilst forming a weak and broad dorsal lobe, very shallow lateral saddles, and a broad shallow ventral lobe with a distinct, narrow saddle over the venter.

The siphuncle is marginal in position and lies on the convex side of the conch. It is circular, or nearly so in section. The mean diameter of the siphuncle is 0.19 of the phragmocone diameter $(0.16,1$ st quartile, $0.22,3 \mathrm{rd}$ quartile, $n=29$ ). The siphuncular segments are deeply concave and appear to be quite strongly thickened.

Stratigraphic and geographic occurrences. Basal Euloma filacovi Zone, St. Chinian Formation, late Tremadocian, and Taihungshania miqueli acme Subzone, La Maurerie Formation, basal Floian, Montagne Noire, Hérault, France.

Discussion. This is the most common and largest cephalopod that occurs in the nodules of the La Maurerie Formation. The fragments of annulated portions of shell belonging to $S$. chinianense account for more than half $(n=121)$ of the determinable cephalopod fragments in the collection $(n=219)$.

As the annulations in $S$. chinianense are often only weakly expressed in fragments less than $20 \mathrm{~mm}$ in diameter, the possibility exists that $S$. chinianense represents more adoral parts of $S$. sericeum. Specimens such as NMW88.30G.8 (Evans 2005, pl. 1, fig. 2) showing a phragmocone and part of the body-chamber with the final septa approximated, whilst lacking any annulations, suggests that this is not the case; as do the large numbers of specimens representing $S$. sericeum (see Evans 2005), all of which that lack any trace of annulation. In addition the relative size of the siphuncle is substantially greater in $S$. sericeum with a mean diameter of $35 \mathrm{~mm}(\mathrm{~N}=14)$. $S$. chinianense differs from $S$. sericeum from the Tremadocian-Floian of the Welsh Borderland, in having an annulated shell, and a narrower siphuncle.

\section{Saloceras murvielense $\mathrm{n}$. sp.}

Figures $6 \mathrm{~J}-\mathrm{L}$

Derivation of name. From Château de Murviel, Murviel-les-Béziers, a wine of the Saint-Chinian region.

Holotype. Specimen FSL 392035 
Type locality and horizon. Type locality and horizon. Euloma filacovi Zone, St. Chinian Formation, late Tremadocian, from Félines-Minervois, Hérault, France.

Material. The holotype and two additional specimens; one specimen (FSL 392037) from Félines-Minervois, and one specimen (FSL 392056) from the surroundings of St. Chinian; all from Hérault, France.

Diagnosis. Rapidly expanding $\left(18^{\circ}\right)$ Saloceras with a nearly straight shell, pronounced annulations of shell, and a slightly compressed cross section; wavelength of single annulation equal to length of 3 camerae; seven camerae in a distance equivalent to dorsoventral diameter of phragmocone; sutures essentially straight with shallow broad lateral saddles; siphuncle marginal with a diameter 0.1 of conch cross section; connecting rings concave and protruding towards centre of siphuncle.

Description. The holotype consists of a portion of phragmocone increasing in diameter from $12.5 \mathrm{~mm}$ to $17 \mathrm{~mm}$ over a distance of $14 \mathrm{~mm}$ (angle of expansion $18.3^{\circ}$ ). The rate of expansion in FSL 392056 is slightly less at $15.4^{\circ}$. Annulations have a wavelength of $6 \mathrm{~mm}$ at a phragmocone diameter of $11 \mathrm{~mm}$, whilst their depth is $0.3 \mathrm{~mm}$. In FSL 392037 annulations have a wavelength of $7 \mathrm{~mm}$ at a phragmocone diameter of $13 \mathrm{~mm}$. Thus there are approximately two annulations in a distance equivalent to the phragmocone diameter. The sutures are almost straight and transverse with weak, broad lateral saddles and a narrow, but faint saddle over the siphuncle. The depth of the camerae ranges from 0.125 to 0.18 of the diameter of the phragmocone cross-section with a mean of $0.148(n=3)$. About three camerae occur in a distance equal to the wavelength of the annulation. The siphuncle is marginal in position, with diameter 0.1 that of the phragmocone. In the holotype, the internal and external moulds of the siphuncle indicated that the connecting rings were strongly concave and thickened.

Stratigraphic and geographic occurrences. Euloma filacovi Zone, St. Chinian Formation, late Tremadocian, Montagne Noire, Hérault, France.

Discussion. This is a distinct species of Saloceras, combining a large angle of expansion with a distinctive pattern of annulation and a comparatively narrow, marginal siphuncle. In these characteristics, this species also appears to be distinct from all other cephalopod taxa of a similar age.

\section{Saloceras pradense (Thoral, 1935)}

\section{Figures 6M, N}

1935 Orthoceras pradense. - Thoral: 190, pl. 15, fig. 5, pl. 16, figs $3 a-3 b$.

Lectotype. USTM-ACI 409 (figured Thoral 1935, pl. 15, fig. 5) is herein selected as the lectotype. From the basal Faunizone $\mathrm{H}=$ Taihungshania miqueli acme Subzone, of the La Maurerie Formation, earliest Floian, from an unspecified location in the environs of St. Chinian, Hérault, France.

Paralectotype. USTM-ACI 419 (figured Thoral 1935, pl. 16, figs 3a, $3 b$ ), from the La Maurerie Formation in the vicinity of Prades-surVernazobres, Hérault, France.
Other material. A total of five specimens (FSL 392032, 392047, 392048, 392054) from the La Maurerie Formation at unspecified locations in the environs of St. Chinian, Hérault, France. One specimen (FSL 392049) from the La Maurerie Formation in the vicinity of Prades-sur-Vernazobres, Hérault, France.

Diagnosis. Slowly expanding (less than $5^{\circ}$ ) species of Saloceras with a nearly circular or slightly depressed conch cross section; conch nearly straight with distinctive, widely spaced constriction; sutures nearly transverse with shallow lateral saddles and weak dorsal and ventral lobes, and a narrow saddle over the siphuncle; eight camerae occur in a distance equal to the phragmocone diameter; siphuncle marginal in position with a diameter approximately 0.25 that of the phragmocone. Connecting rings concave and thickened.

Description. The lectotype consists of body-chamber and phragmocone $61 \mathrm{~mm}$ in length of which the bodychamber represents $31 \mathrm{~mm}$. The lateral diameter of the phragmocone is $18 \mathrm{~mm}$ near the base of the bodychamber. The shell increases in diameter from $15 \mathrm{~mm}$ to $19 \mathrm{~mm}$ over its length, giving a rate of expansion of $3.9^{\circ}$. The body-chamber shows two constrictions about $11 \mathrm{~mm}$ apart and in the case of the more apically positioned, is $6.5 \mathrm{~mm}$ long and lies close to the base of the body-chamber. The depth of the camerae are 0.125 that of the phragmocone diameter. The paralectotype represents the largest individual recorded, reaching a dorsoventral diameter of $27 \mathrm{~mm}$ at the base of the bodychamber where the camerae are 0.08 of the dorsoventral diameter of the phragmocone. This specimen shows well-developed lateral saddles, combined with a broad lobe on the venter, which is inflected over the siphuncle to form a marked saddle. The siphuncle shows that the connecting rings must be markedly concave and probably thickened.

FSL 392032 consists of part of a body-chamber $22.5 \mathrm{~mm}$ long and a portion of the phragmocone consisting of three camerae, giving a total length to the fragment of $35 \mathrm{~mm}$. It increases in its dorsoventral diameter from $19.5 \mathrm{~mm}$ to $21 \mathrm{~mm}$ in a distance of $28 \mathrm{~mm}$ giving a rate of expansion of $4.5^{\circ}$. The cross-section is almost circular, but very slightly depressed. The surface of the mould of body chamber shows very faint annulations that are parallel to the sutures and $1 \mathrm{~mm}$ to $2 \mathrm{~mm}$ apart and form a shallow v-shaped ventral sinus. The body chamber is constricted $7 \mathrm{~mm}$ aperturally of the last septum. The constriction is $9 \mathrm{~mm}$ in length and $1 \mathrm{~mm}$ in depth. In FSL 392048, the distance between two succeeding constrictions is $12 \mathrm{~mm}$ at a conch cross section of $20 \mathrm{~mm}$.

In this specimen the sutures are almost transverse, but slightly inclined towards the aperture on the dorsal side of the phragmocone. The distance between the sutures is $2.3 \mathrm{~mm}$ giving a cameral depth 0.12 of the phragmocone diameter. In FSL 392047 a broad, vshaped ventral saddle is visible.

Overall, the mean of the relative depth of the camerae is $0.13(n=5)$, but is very low in the paralectotype and may indicate that the septa are approximated in this specimen, possibly indicating the maximum size of this taxon. The relative diameter of the siphuncle 
varies between 0.17 and 0.31 of the phragmocone diameter (mean $=0.24, n=5$ ) and appears to decrease adorally. The connecting rings are deeply concave and likely to be thickened.

Stratigraphic and geographic occurrences. Basal Faunizone $\mathrm{H}=$ Taihungshania miqueli acme Subzone, of the La Maurerie Formation, basal Floian, Montagne Noir, Hérault, France.

Discussion. Thoral (1935) noted that O.pradense was characterised by the annulations that occur on the body-chamber and also the approximation of the two last camerae. He noted also the similarity to O. estivale in the form and position of the siphuncle as well as their occurrence in the same horizons. S. pradense is easily distinguished from other species of Saloceras in possessing a very low rate of expansion and marked constrictions of the shell. O. estivale is here synonymised with $S$. chinianense as it possesses a higher rate of expansion, and lacks the characteristic constrictions on the body-chamber.

\section{Family Rioceratidae n. fam.}

Derivation of the name. From Rioceras Flower, 1964, the type genus. Type genus. Rioceras Flower, 1964.

Diagnosis. Slender, orthoconic ellesmerocerids with essentially simple, straight, transverse sutures, and thin marginal, or nearly so siphuncle; sutures may form ventral lobe; septal necks achoanitic through loxochoanitic to nearly orthochoanitic; siphuncular segments concave, with thick connecting rings; endosiphuncular and cameral deposits unknown; diaphragms may be present in some forms.

Discussion. In emending the Baltoceratidae and restricting the family to Orthocerida taxa similar to Cochlioceras Eichwald, 1860, Kröger et al. (2007) excluded those genera possessing concave siphuncular segments with thickened connecting rings such as Rioceras Flower, 1964 originally included in the Baltoceratidae by Flower (1964). Similarly, revision of Protocycloceras lamarcki (Billings, 1859) by Kröger \& Landing (2009) has restricted the Protocycloceratidae to rod-bearing, annulate longicones of the Ellesmerocerida with concave siphuncular segments. As a consequence of these more restricted diagnoses Kröger \& Landing (2009) indicated that the remainder of the original Baltoceratidae were orphaned and the erection of a new higher taxon was required. Herein, we erect this higher taxon as a family that includes straight longiconic ellesmerocerids with a siphuncle with concave siphuncular segments, thick connecting rings, and which are free of endosiphuncular deposits. The Cyptendoceratidae, and the Protocycloceratidae differ in having an endosiphuncular rod, and the Baltoceratidae differ in having a thin, tubular connecting ring.

Genera included. Rioceras Flower, 1964; Felinoceras n. gen.; Microbaltoceras Flower, 1964; Pachendoceras Ulrich \& Foerste, 1936.

\section{Genus Rioceras Flower, 1964}

Type species. Rioceras nondescriptum Flower, 1964, by original designation. From the Victorio Formation of the El Paso Group of New Mexico, southwestern United States.

Diagnosis. Small slender orthocones expanding at rates between $5^{\circ}$ and $25^{\circ}$; circular to slightly compressed or depressed cross-sections; shell smooth; sutures generally straitght and directly transverse; camerae shallow, depth 0.1-0.2 dorsoventral diameter of phragmocone; body-chamber simple, tubular or faintly fusiform; septal necks loxochoanitic-orthochoanitic; siphuncle marginal, with diameter of about 0.4-0.1 of dorsoventral phragmocone diameter, segments concave with moderately thick connecting rings; no or strongly reduced endosiphuncular deposits.

Discussion. Known from several species described by Flower (1964) from horizons of Stairsian to Blackhillsian age in the El Paso Group of the southwestern United States, Rioceras, despite its simple form, exhibits wide variation in the rate of expansion of the shell and some variation in the relative diameter of the siphuncle. Given the range of variation, particularly in the rate of expansion of the shell, it may be the case that taxa such as R.(?) lobatum Flower should be assigned to a separate genus. The structure of the siphuncle in $R$. nondescriptum (Flower 1964, pl. 19, figs 10, 18, 21), R. oaxacaense (Flower 1968, pl. 105, fig. 4) and R. sp. (Flower 1968 , pl. 105, figs 9-11) shows a connecting ring characteristic of many ellesmerocerids insofar as it is thickened and slightly concave in profile. The thickening of the connecting rings is greatest at the apical end of the segments, indicating that they are attached to relatively long septal necks that are certainly loxochoanitic and may approach an orthochoanitic state. Forms such as Rioceras? sp. (Hook \& Flower 1977, pl. 12, figs 18 20) from the Wahwah Limestone of Utah do not belong in the genus as the connecting rings are thin and convex in profile.

The bulk of species assigned to Rioceras are from the early Ordovician of the southwestern United States. Evans $(2005,70)$ considered that the species assigned to Rioceras by Flower (1968) from the Tiñu Formation of Oaxaca State, Mexico, were related to Saloceras. This interpretation was at least in part based upon the profiles of the connecting rings illustrated by Flower (1968, pl. 42, figs 5-6), which represent sagittal sections in the dorsoventral plane of the siphuncle. These sections are, however, cut obliquely to the dorsoventral plane and exaggerate the apparent thickness of the connecting ring, generating a superficial resemblance to Saloceras.

\section{Rioceras escandei (Thoral, 1935)}

Figures $6 \mathrm{P}-\mathrm{V}, 7 \mathrm{~A}, \mathrm{~B}$

1935 Orthoceras escandei. - Thoral: 186, pl. 15, figs 2-3.

1935 Orthoceras estivali variété brevicellae. - Thoral: 189, pl. 15, fig. 4.

1935 Orthoceras sp. II. - Thoral: 191, pl. 16, figs 4a-4d.

Lectotype. USTM-ACI 406, figured by Thoral (1935, pl. 15, fig. 2). 
Paralectotype. USTM-ACI 406, figured by Thoral (1935, pl. 15, fig. 3).

Type locality and horizon. Asaphelina barroisi berardi + Taihungshania miqueli Subzone, latest Tremadocian, St. Chinian Formation, St. Chinian, La Croix-Rouge, Hérault, France.

Other material. A total of 32 specimens; from the Euloma filacovi Zone, late Tremadocian, St. Chinian Formation, Félines-Minervois, Hérault (4 specimens: FSL 392044, 392207, 392235, 392289), the Asaphelina barroisi berardi + Taihungshania miqueli Subzone, late Tremadocian, NE school of Prades-sur-Vernazobres, Hérault (12 specimens: FSL 392178, 392181, 392198-99, 392201-03, 392205, 392233, 392249-50, 392252), and St. Chinian, La Croix-Rouge, Hérault (1 specimen: FSL 392246), and the Taihungshania miqueli acme Subzone, early Floian, Prades-sur-Vernazobres, Canto Cigale, Hérault (11 specimens: FSL 392180, 392187, 392191-93, 392195-97, 392210, 392218, 392222), and Prades-sur-Vernazobres, La Maurerie, Hérault (4 specimens: FSL 392206, 392208, 392215, 392231).

Diagnosis. Straight conchs with apical angle of $6^{\circ}$, circular to slightly depressed cross section; smooth or faintly and irregularly annulated shell. Five chambers occur in a distance similar to phragmocone diameter. Sutures almost directly transverse and nearly straight with a weak lobe over the venter. Siphuncle marginal in position, with a diameter 0.2 that of the phragmocone; nearly tubular in outline, with segments only slightly concave.

Description. The lectotype consists of an internal mould $53 \mathrm{~mm}$ long, of which $42 \mathrm{~mm}$ represents a phragmocone that increases in diameter from $12.5 \mathrm{~mm}$ to $13.8 \mathrm{~mm}$ giving a rate of expansion of $3.5^{\circ}$. The depth of the camerae ranges from 0.23 to 0.33 that of the diameter of the phragmocone, whilst the sutures are almost directly transverse, with a shallow lobe over the siphuncle. The siphuncle is marginal in position and relatively narrow in diameter. The visible ventral surface of the mould of the siphuncle shows that the segments are slightly constricted and the connecting rings may be interpreted as concave in shape. The mould of the septal foramen forms a narrow ridge directed adorally over the ventral surface of the siphuncle suggesting the presence of a short septal neck.

The other specimens consist of internal moulds of orthoconic longicones with an apical angle that varies between $4^{\circ}$ (1st quartile) and $7^{\circ}$ (3rd quartile) in the 10 specimens where this measurement is possible. The surface of the shell is almost smooth with very weak irregularly spaced transverse undulations (specimen FSL 392289) that form a very shallow sinus over the venter. The largest specimen observed (FSL 392209) has a diameter of $22 \mathrm{~mm}$. The cross section of the shell varies from circular to a maximum width/height ratio of 1.16 (mean $=1.04, n=15)$. In only a few specimens are the septa well enough preserved to estimate their depth. These show some variation, ranging from 0.9 that of the phragmocone diameter to 0.28 with a mean of $0.16(n=6)$. Cameral depth varies between 0.16 of the phragmocone diameter (1st quartile) and 0.22 (3rd quartile) with a mean of 0.2 in 18 specimens from which measurements were possible. There is some indication that cameral depth generally decreases with increasing phragmocone diameter, although this is poorly correlated (Fig. 8). The sutures seen in FSL
392207 and FSL 392208 are nearly straight and very slightly obliquely inclined toward the aperture on the dorsal side, with a very weak lobe over the venter. The siphuncle is marginal in position and in the 25 specimens measured, the diameter varies between 0.19 that of the phragmocone diameter (1st quartile) and 0.27 (3rd quartile) with a mean of 0.23 . In no specimen is the siphuncle well-enough preserved to be able to distinguish between the septal necks and the connecting rings with certainty. Both FSL 392187 and 392203 demonstrate that the siphuncular segments are slightly concave (Figs 6P, 7A), whilst the ventral surface of the siphuncle visible in FSL 392207 may suggest that the inner surface of the segments are more strongly deflected at their apical ends. This could be interpreted as a weakly concave connecting ring that increased in thickness towards its apical termination, and may indicate that the septal necks were loxochoanitic or orthochoanitic, but fairly short, so that no indication of their presence would be expected to be evident on the mould of the siphuncle.

Comparison. Rioceras escandei differs from many of the species of Rioceras described from North America. R. lobatum Flower, 1964 possesses lateral lobes, a greater rate of expansion and a broader siphuncle. $R$. depressum Flower, 1964 has a broader siphuncle and more strongly depressed cross-section, whilst $R$. dartoni Flower, 1964 expands more rapidly and the camerae are extremely shallow. R. nondescriptum Flower, 1964 bears some similarity to $R$. escandei, but possesses a slightly larger siphuncle, shallower camerae, and a smaller rate of expansion. Whilst the rate of expansion is slightly greater, $R$. escandei is closest to $R$. minore Flower, 1964 and $R$. oaxacaense, from the Tremadoc Tiñu Formation of Oaxaca State, Mexico. If more material were available from the Tiñu Formation, it may be possible to demonstrate that these species are junior synonyms of $R$. escandei.

Stratigraphic and geographic occurrences. Euloma filacovi Zone and Asaphelina barroisi berardi + Taihungshania miqueli Subzone, St. Chinian Formation, late Tremadocian, to basal Faunizone $\mathrm{H}=$ Taihungshania miqueli acme Subzone, basal Floian, of the La Maurerie Formation, Montagne Noir, Hérault, France.

\section{Genus Felinoceras n. gen.}

Deriviation of the name. Referring to the type locality of the genotype, Félines-Minervois, Hérault, France.

Type species. Felinoceras constrictum n. sp. from the Euloma filacovi Zone, St. Chinian Formation, late Tremadocian, Hérault, France.

Diagnosis. Annulated orthocones expanding at approximately $12^{\circ}$; cross section circular to slightly depressed; annulations directly transverse more pronounced in earlier growth stages, with widely spaced, directly transverse constrictions; about 2 annulations in a distance equal to the corresponding conch diameter; sutures directly transverse, 5 in a distance equal to the corresponding phragmocone diameter; about 2 camerae in a distance equal to one annulation; 

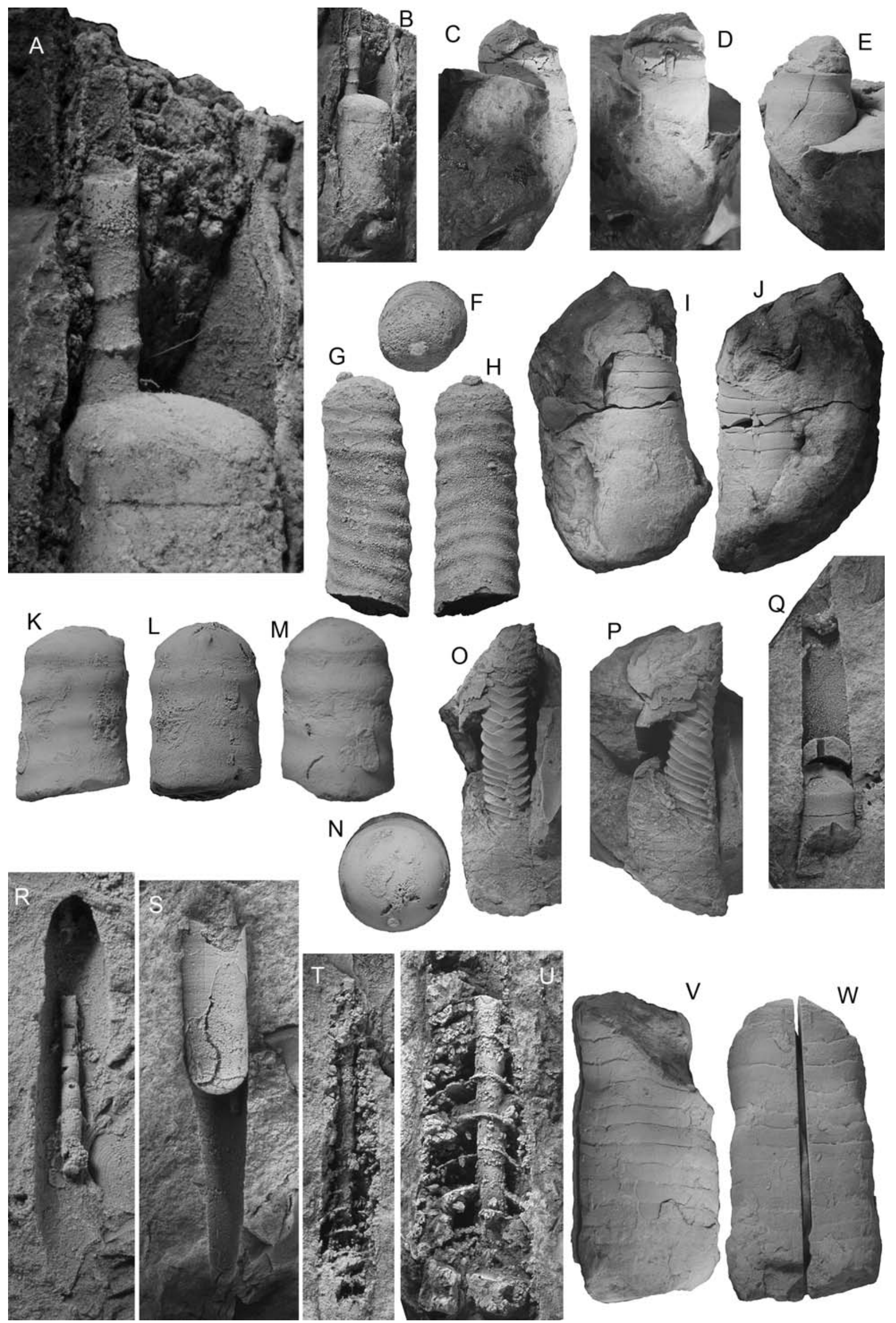
siphuncle marginal, diameter approximately 0.1 of phragmocone diameter; segments slightly concave in profile.

Comparison. Felinoceras may be compared with several annulate orthocones of late Tremadoc or early Floian age. Rudolfoceras Ulrich, Foerste, Miller \& Unklesbay 1944 differs from Felinoceras in possessing a slightly narrower siphuncle that is removed from the phragmocone wall, whilst the camerae are shallower and there are about seven camerae between each annulation. In Ectocycloceras Ulrich \& Foerste, 1936 the annulations are relatively suppressed by comparison with those of Felinoceras, whilst the camerae of the former are substantially shallower. Ectocycloceras also differs in the marked curvature of the shell and the relatively low rate expansion of the shell as well as the slight contraction of the body-chamber. The orthocerid Kyminoceras Teichert \& Glenister, 1954 is superficially similar to Felinoceras and although it clearly differs in the much lower rate of expansion of the conch, the more significant difference is in the possession of thin, slightly convex connecting rings. Felinoceras differs from Rioceras in having an annulated shell

Species included. Type species only.

\section{Felinoceras constrictum n. sp.}

Figures $7 \mathrm{C}-\mathrm{E}, \mathrm{I}-\mathrm{J}$

Deriviation of the name. Referring to the characteristic conch constrictions of the holotype.

Holotype. Specimen FSL 392225.

Paratype. Specimen FSL 392286.

Type locality and horizon. Euloma filacovi Zone, St. Chinian Formation, late Tremadocian, from Félines-Minervois, Hérault, France.

Diagnosis. As for genus by monotypy.
Description. The holotype is an orthoconic portion of phragmocone with a total length of $38 \mathrm{~mm}$, increasing in diameter over a distance of $14 \mathrm{~mm}$ from $12 \mathrm{~mm}$ to $15 \mathrm{~mm}$ (angle of expansion $12^{\circ}$ ). The maximum diameter of the specimen is $17 \mathrm{~mm}$. The cross section of the conch is nearly circular. The annulations are straight, directly transverse and about $6 \mathrm{~mm}$ distance, with an amplitude $0.4 \mathrm{~mm}$ where the phragmocone diameter is $13 \mathrm{~mm}$. At conch a diameter larger than $15 \mathrm{~mm}$ annulations appears to become very shallow, inconspicuous and the distance between crests increases to about $10 \mathrm{~mm}$. The sutures are straight, directly transverse and distance 0.19 of corresponding phragmocone diameter. The siphuncle is marginal in position with a diameter of $2 \mathrm{~mm}$ where the phragmocone diameter is $13 \mathrm{~mm}$ (or 0.15 of the phragmocone diameter). The siphuncular segments are almost tubular, but slightly concave in profile.

The paratype is a piece of phragmocone and bodychamber with a total length of $40 \mathrm{~mm}$ with a minimum diameter of $10 \mathrm{~mm}$, increasing to $12.5 \mathrm{~mm}$ over $7 \mathrm{~mm}$. A single directly transverse constriction is present at a diameter of $10 \mathrm{~mm}$. The constriction is approximately $7 \mathrm{~mm}$ wide and $0.5 \mathrm{~mm}$ deep. The conch cross-section is slightly flattened on the antisiphuncular side of the shell. The sutures are directly transverse $1.9 \mathrm{~mm}$ distance where the phragmocone diameter is $10 \mathrm{~mm}$. The siphuncle is marginal, and with a relative diameter 0.1 that of the phragmocone diameter is slightly less than that of the holotype.

Discussion. Felinoceras constrictum n. sp. is superficially similar to the co-occurring annulate orthocone Saloceras murvielense $\mathrm{n}$. sp., which has a similar rate of expansion. S. murvielense possesses generally shallower camerae whilst the siphuncular segments are

Figure 7. Ellesmerocerida, Endocerida, and Orthocerida of the Early Ordovician of the Montagne Noire. A-B. Rioceras escandei (Thoral, 1935). St. Chinian and La Maurerie Formation. FSL 392203. Northeast of the school, Prades-sur-Vernazobre, Canto Cigale, Hérault; A. Detail of siphuncle showing the septal foraminae and weakly concave segments. $\times 4.0$. B. General view of the same specimen, showing the adoral end of the phragmocone and the body-chamber. $\times 1.0 ; \mathbf{C}-\mathbf{E}, \mathbf{I}-\mathbf{J}$. Felinoceras constrictum n. sp. St. Chinian and La Maurerie Formation, Félines-Minervois, Hérault; C-E. FSL 392286; C. Lateral view of weakly annulated body-chamber and phragmocone (venter on left). $\times 1.25$; D. Ventral view showing trace of siphuncle on the venter. $\times 1.25$; E. Lateral view (venter on right). $\times 1.25$; I-J. FSL 392225; I. Lateral view of faintly annulated body-chamber and phragmocone (venter on right). $\times 1.0$; J. Lateral view showing trace of siphuncle on venter in the form of small saddles formed ny the sutures. $\times 1.0 ; \mathbf{F}-$ H, Q. Annbactroceras martyi (Thoral, 1935). FSL 392227. St. Chinian Formation, Félines-Minervois, Hérault; F. Septal view of body-chamber showing septal foramen (venter down). $\times 2.0$; G. Lateral view of annulate body-chamber (venter on left). $\times 2.0$; H. Ventral view of body-chamber. $\times 2.0$; $\mathbf{Q}$. Adventitious section through phragmocone showing deep camerae and tubular siphuncular segments. FSL 424983. St. Chinian, Hérault. $\times 2.5$; K-N. Annbactroceras felinense n. sp. FSL 392223. La Maurerie Formation. Félines-Minervois, Hérault; K. Lateral view of annulate body-chamber (venter on right). $\times 1.25$; L. Ventral view showing septal foramen. $\times 1.25$; M. Dorsal view. $\times 1.25$; N. Septal view showing septal foramen (venter down). $\times 1.25 ; \mathbf{R}-\mathbf{S}$. Bactroceras mourguesi (Thoral, 1935). La Maurerie Formation; R. External mould of phragmocone containing a partially silicified siphuncle showing markedly expanded segments. FSL 392219. Prades-sur-Vernazobre, la Maurerie, Borie des Pierils, Canto Cigale, Hérault. $\times 5.0$; S. Body-chamber and external mould of phragmocone. FSL 392263. Félines-Minervois, Hérault. $\times 4.0 ;$ O-P, V-W. Lobendoceras undulatum n. sp. La Maurerie Formation, Félines-Minervois, Hérault; O-P. FSL 392270; O. Internal mould of part of body-chamber, phragmocone and large siphuncle. $\times 1.25$; P. Lateral view (venter on right). $\times 1.25$; V-W. FSL 392277 ; V. Lateral view of phragmocone showing inclined transverse constriction towards apical end (venter on left). $\times 1.0$; W. Ventral view of phragmocone showing constricion over venter. $\times 1.0 ;$ T-U. Cochlioceras? aff. roemeri Dzik, 1984. St. Chinian and La Maurerie formations; T. FSL 392232. Adventitious section through phragmocone showing siphuncle. Northeast of the school, Prades-sur-Vernazobre, Canto Cigale, Hérault. $\times 3.0$; U. FSL 392182 . Adventitious section through phragmocone showing a relatively broad siphuncle with slightly expanded segments. Prades-sur-Vernazobres, Canto Cigale, Hérault. $\times 3.0$. 
markedly concave in profile and the annulations are more distant. In the nearly tubular siphuncle and the comparatively deep spaced camerae, F. constrictum is similar to Rioceras escandei in having a slender straight conch with a thin, marginal siphuncle with concave siphuncular segments, lacking any evidence for endosiphuncular deposits, and it is for this reason that the genus is assigned to the Rioceratidae.

Stratigraphic and geographic occurrences. Euloma filacovi Zone, St. Chinian Formation, late Tremadocian, Montagne Noire, Hérault, France.

\section{Subclass Orthoceratoidea Zhuravleva, 1994 \\ Order Orthocerida Kuhn, 1940 \\ Family Baltoceratidae Kobayashi, 1935}

\section{Genus Annbactroceras n. gen.}

Derivation of name. From the latin annulare, referring to the characteristic ornamentation of this genus

Type species. Annbactroceras martyi (Thoral, 1935) from the Euloma filacovi Zone, St. Chinian Formation, late Tremadocian, Hérault, France.

Diagnosis. Slender, straight to slightly curved, annulate conchs; sutures directly transverse and widely spaced; siphuncle marginal to eccentric in position and closer to side of conch with concave curvature; septal necks orthochoanitic, siphuncular segments tubular with a diameter 0.1 that of phragmocone diameter.

Comparison. This genus differs from Bactroceras Holm, 1898 in possessing an annulated shell, and from Slemmestadoceras Kröger, 2008, in possessing deep camerae and a lower angle of expansion. Kyminoceras Teichert \& Glenister, 1954 also shows similarities in the composition of the siphuncle, although as with Slemmestadoceras, the camerae appear to be somewhat shallower.

Species included. Annbactroceras martyi (Thoral, 1935); Annbactroceras felinense n. sp.

\section{Annbactroceras martyi (Thoral, 1935)}

Figures 7F-H, Q

1935 Orthoceras martyi. - Thoral: 180, pl. 15, figs 9a-9c.

Holotype. USTM-ACI 413

Type locality and horizon. Euloma filacovi Zone, St. Chinian Formation, late Tremadocian, Prades-sur-Vernazobres, Hérault, France.

Material. Six specimens, all from the Euloma filacovi Zone, St. Chinian Formation, late Tremadocian: four (FSL 392224, 392227, 392287-88) from Félines-Minervois, one (FSL 424983) from the vicinity of St. Chinian in a nodule with Aethocrinus moorei (Ubaghs, 1969), figured in Ubaghs (1969, pl. 1, fig. 6), specimen FSL 392292 is from Vigne Bolo, La Rouvelane, Hérault, France.

Diagnosis. Slender, annulate slightly curved conchs with angle of expansion of typically less than $5^{\circ}$, and circular cross section; annulations form shallow lobe at prosiphuncular side, 4-5 annulations per distance similar to conch diameter; sutures directly transverse, with distance of approximately 0.5 of corresponding conch height; siphuncle eccentric, positioned between conch center and concave side of conch curvature, tubular with diameter of 0.1 of conch cross section.
Description. The holotype consists of a portion of phragmocone $58 \mathrm{~mm}$ long, increasing from $7.5 \mathrm{~mm}$ to $8.7 \mathrm{~mm}$ in the same distance, giving an expansion rate of $1.2^{\circ}$. The cross-section of the shell is weakly elliptical and may be slightly deformed. Eight annulations are present along the most adoral $22 \mathrm{~mm}$ of the phragmocone. They are inclined to the normal of the conch axis by about $17^{\circ}$ and form a sinus on the prosiphuncular side of the phragmocone. Several camerae are visible toward the apical end of the specimen, and these indicate that the sutures are straight and directly transverse. However, deformation of the apical end of the specimen prohibits anything more than an estimation of the depth of the camerae, which in one case is estimated at 0.32 the diameter of the phragmocone. The siphuncle is clearly submarginal in position and tubular in profile, but again the deformation of this part of the conch prohibits measurement of the siphuncle.

The material described here consists of somewhat fragmentary portions of conch representing both phragmocones and body-chambers. Overall, the shell is slender and slightly curved with siphuncle lying on the side of the shell that has a concave curvature (FSL 392227 , 424983). Shell fragments range from $12 \mathrm{~mm}$ to $22 \mathrm{~mm}$ with the smallest shell diameter being $2.5 \mathrm{~mm}$ (FSL 424983), and the largest represented by the adoral end of FSL 392227, which consists of a body-chamber. The rate of expansion of the shells ranges from $2^{\circ}$ to $5^{\circ}$. Sutures are straight and directly transverse in all specimens where they are visible. Where septa are visible, the depths of the septa are estimated at 0.25 of the phragmocone diameter. Cameral depth ranges from 0.18 to 0.54 of the phragmocone diameter, but lies mainly between 0.4 and 0.5 , whilst the lowest value (0.18, FSL 392288) may represent an approximated septum just below the body-chamber. The diameter of the siphuncle varies from 0.07 to 0.22 of the phragmocone diameter whilst its position is submarginal with its ventral wall lying at a distance between 0.09 and 0.33 of the phragmocone diameter from the venter. As seen in FSL 424983, the mould of the siphuncle is tubular, or very slightly expanded throughout the length of the siphuncular segment, indicating probable thin connecting rings and orthochoanitic septal necks. Annulations are present in all specimens but appear to be extremely suppressed in FSL 424983, with some indication of their presence in the sagittal profile of the adoral part of the external mould in this specimen. Annulations are about $0.1 \mathrm{~mm}$ in depth from crest to trough, and range from $2 \mathrm{~mm}$ to $3 \mathrm{~mm}$ from crest to crest. They are slightly inclined towards the aperture in the antisiphuncular side of the shell and form indistinct shallow lobes on the prosiphonal side. FSL 392227 consists entirely of a body-chamber $20 \mathrm{~mm}$ long and $6 \mathrm{~mm}$ in diameter at the base and shows a distinct curvature.

Stratigraphic and geographic occurrences. Euloma filacovi Zone, St. Chinian Formation, late Tremadocian, Montagne Noire, Hérault, France. 
Discussion. Annbactroceras martyi is represented by a relatively small number of individuals that exhibit some discontinuous variation in a number of characters. It is possible, given additional specimens, that these discontinuities would be reduced. However, given the data available, questions may arise with regard to whether all the material belongs to the same taxon. The difference in cameral depths seen in this material may be reflected in the fact that the specimen in question (FSL 392288) has a maximum diameter of $8 \mathrm{~mm}$ which is larger than the body-chamber represented by FSL 392227 , suggesting the possibility that the septa are approximated in the former specimen, as this part of the shell may be close to the body-chamber. Whilst there is a wide range in the siphuncle diameter, similarly wide ranges occur in other taxa described here (e.g. Saloceras chinianense or Rioceras escandei). The variation seen in the degree of development of the annulation of the shell may be more a reflection of the small size of the shell represented by FSL 424983, especially as it annulations appear to be better developed in the adoral portion of this specimen.

Thoral (1935) noted that Slemmestadoceras attavus (Brøgger, 1882) resembled A. martyi, but that the latter differs in possessing a greater angle of expansion, a less pronounced annulation, and a narrower, strictly marginal siphuncle. Miquel (1912) listed Orthoceras attavum Brøgger, 1882 from the "Schistes à Symphysurus sicardi" (Thoral 1935, 85). Here, this is taken as evidence of the occurrence of an annulate longicone in the Faunizones E/F of the St. Chinian Formation. The presence of two specimens from the Tremadocian of the St. Chinian Formation in the FSL collections, support Miquel's (1912) observation and confirm a Tremadocian age for the oldest A. martyi. Together with the sporadic occurrence of Bactroceras mourguesi (Thoral, 1935) in the St Chinian Formation these taxa currently represent the oldest occurrences of orthocerid taxa.

\section{Annbactroceras felinense $\mathbf{n}$. sp.}

Figures $7 \mathrm{~K}-\mathrm{N}$

Deriviation of the name. Referring to the type locality, Félines-Minervois, Hérault, France.

Holotype. Specimen FSL 392223.

Type locality and horizon. Euloma filacovi Zone, St. Chinian Formation, late Tremadocian, from Félines-Minervois, Hérault, France.

Material. Holotype only.

Diagnosis. Slender, annulate, slightly curved conch with low angle of expansion, and slightly compressed cross section; annulations form sharply rounded crests and broadly rounded troughs; slightly inclined towards aperture on antisiphuncular side of conch; 4 annulations in distance equal to conch diameter; fine striations present parallel to annulations; sutures straight and directly transverse; siphuncle marginal on side of conch with concave curvature; tubular with diameter of 0.1 that of conch diameter.

Description. The holotype is a slender, slightly curved fragment of a body-chamber $24 \mathrm{~mm}$ long with the final septum preserved at its base. It increases in diameter from $14.4 \mathrm{~mm}$ to $15.4 \mathrm{~mm}$ over a distance of $16 \mathrm{~mm}$, giving angle of expansion $3.6^{\circ}$. The conch cross section is slightly compressed (lateral diameter/dorsoventral diameter $=0.96$ ). Annulations are approximately $4 \mathrm{~mm}$ apart, and slightly inclined toward the aperture on the antisiphuncular, convex side of the shell, forming a very broad sinus on the prosiphuncular side. The annulations form sharp angular crests combined with broadly rounded troughs and have an amplitude of $0.2 \mathrm{~mm}$. Fine striations with a density of 5 per $\mathrm{mm}$ are present parallel to the annulations. The suture at the base of the body-chamber is straight and transverse with a broad and shallow saddle on the antisiphuncular side of the shell. The siphuncle is marginal in position on the side of the conch with concave curvature. At a conch diameter of $14 \mathrm{~mm}$, the diameter of the siphuncle is $1.5 \mathrm{~mm}$. Only the adoral end of the siphuncle is preserved, but what remains suggests that the septal necks were orthochoanitic, and the connecting rings tubular.

Stratigraphic and geographic occurrences. Euloma filacovi Zone, St. Chinian Formation, late Tremadocian, Montagne Noire, Hérault, France.

Discussion. By comparison with Annbactroceras martyi (Thoral, 1935), A. felinense is larger in size, possesses a marginal siphuncle, whilst the ventral sinus formed by the annulations is less pronounced than those seen in A. martyi.

\section{Genus Bactroceras Holm, 1898}

Type species. Bactroceras avus Holm, 1898, subsequent designation by Glenister $(1952,90)$.

Diagnosis. Slender, smooth orthocones with nearly circular cross sections; camerae generally deep; sutures straight and directly transverse; siphuncle marginal or slightly removed from conch margin, with diameter about 0.1 that of phragmocone, septal necks orthochoanitic, siphuncular segments tubular to slightly inflated with thin connecting rings; endosiphuncular deposits unknown. (Compiled from Holm 1898 \& Evans 2005)

\section{Bactroceras mourguesi (Thoral, 1935)}

Figures $7 \mathrm{R}-\mathrm{S}$

1935 Orthoceras mourguesi. - Thoral: 185, pl. 15, figs 10a-10b. 1946 Endoceras sp. - Thoral: 51, pl. 5, figs 2a-2b.

Holotype. USTM-ACI 414

Type locality and horizon. Euloma filacovi Zone, St. Chinian Formation or basal Faunizone $\mathrm{H}=$ Taihungshania miqueli acme Subzone, of the La Maurerie Formation, latest Tremadocian to earliest Floian, St. Chinian, Hérault, France.

Material. A total of 32 specimens; 29 are from the type horizon; 5 specimens (FSL 392264-392268) from Cabrières; 16 specimens (FSL 392236-392244, 392253-392256, 392263, 392285, 392290) from Félines-Minervois; 1 specimen (FSL 392220) from Prades-surVernazobres, Canto Cigale; 2 specimens (FSL 392177, 392179, 392219) from Borie des Pierils, Prades-sur-Vernazobres, Canto Cigale; 1 specimen (FSL 392283) from Prades-sur-Vernazobres, La 
Maurerie; 4 specimens (FSL 392228, 392247, 392248, 392257) from St. Chinian and surrounding area, and specimen FSL 392291 is from Prades-sur-Vernazobres, La Rouvelane, vigne Bolo; all Hérault, France. One specimen (FSL 1534; Thoral 1946, 51, pl. 5, fig. 2a, b) from Faunizone $\mathrm{K}=$ Neseuretus $(N$.) arenosus Zone of the environs of Cabrières.

Diagnosis. Bactroceras with angle of expansion of approximately $8^{\circ}$, circular cross section and slightly curved conch in juvenile stages. Shell smooth or with faint transverse striae; faint, narrow, regularly spaced annulations may occur in some individuals. Two chambers in distance equal to phragmocone diameter. Sutures directly transverse, but with a sharp ventral lobe over the siphuncle. Siphuncle marginal; diameter 0.17 of corresponding phragmocone diameter; septal necks orthochoanitic; segments tubular to slightly inflated.

Description. The holotype consists of a portion of phragmocone $27 \mathrm{~mm}$ long and $6.5 \mathrm{~mm}$ in diameter. The phragmocone consists of five camerae ranging in depth from 0.46 to 0.7 of the diameter of the phragmocone. The sutures are straight and directly transverse with a sharp, narrow and shallow lobe over the siphuncle. The siphuncle is marginal and its diameter 0.1 that of the phragmocone. The siphuncle is sufficiently removed from the wall of the phragmocone to not leave a trace on the surface of the internal mould.

The remaining material consists of a variety of specimens consisting of portions of phragmocones with a few body-chambers ranging from a minimum diameter of $2.3 \mathrm{~mm}$ (FSL 322263, 322265, 322179) to a maximum of $17 \mathrm{~mm}$ (FSL 322267). The conch is straight, but shows a slight curvature in the earliest growth stages where the siphuncle lies on the side of the shell where the profile of the curvature is convex. The cross-section of the conch is almost invariably circular, whilst the mean angle of expansion is $6.6^{\circ}(n=9)$ with a maximum of $3.0^{\circ}$ (FSL 392253 ) and a maximum of $13.5^{\circ}$ (FSL 392267).

The sutures are straight and directly transverse, sometimes with sharp, and narrow lobes over the septal foramen. The camerae range in depth from of 0.25 to 0.74 that of the phragmocone diameter with a mean of $0.45(n=14)$.

The siphuncle is marginal in position whilst its diameter ranges from 0.07 (FSL 392224) to 0.27 (FSL 322219 ) that of the phragmocone diameter, with a mean diameter of $0.16(n=16)$. A sharp transition from the surface of the septal foramen to the surface of the mould of the connecting ring (FSL 392043, 392179) indicates that the septal necks are orthochoanitic. The connecting rings are thin and the siphuncular segments range from tubular to slightly inflated (FSL 392219) in their profile.

In some specimens the surface of the shell possesses faint transverse striae that are slightly inclined toward the aperture on the (antsiphonal) dorsal side of the shell. FSL 392253 is a shell with fine, regularly spaced undulations that are $1 \mathrm{~mm}$ wide, and show a similar slight inclination as the striae seen in other specimens. This specimen which represents a complete body-chamber with a length of $25 \mathrm{~mm}$, and a diameter increasing from $10.3 \mathrm{~mm}$ to $11.3 \mathrm{~mm}$ (angle of expansion $=2.3^{\circ}$ ) has a $5 \mathrm{~mm}$ wide shallow constriction circumscribing the internal mould $19 \mathrm{~mm}$ from the base of the bodychamber, suggesting that the specimen represents a mature individual.

Stratigraphic and geographic occurrences. Euloma filacovi Zone, late Tremadocian, basal Faunizone $\mathrm{H}=$ Taihungshania miqueli acme Subzone, basal Floian, of the La Maurerie Formation to Neseuretus (N.) arenosus Zone, mid Floian, Montagne Noire, Hérault, France (after J. C. Gutiérrez-Marco, unpubl. data, faunizones I-K would be equivalent to the balticus graptolite Zone, i.e. mid Floian, IGCP 410 Timeslice 2b).

Discussion. Bactroceras mourguesi is unique within Bactroceras in having a fairly high angle of expansion and a slightly curved conch in juvenile stages. Together with the rare occurrences of Annbactroceras martyi, in the St. Chinian Formation, B. mourguesi represents the oldest members of the Orthocerida currently known.

\section{Genus Cochlioceras Eichwald, 1860}

Type species. Cochlioceras avus Eichwald, 1860.

Diagnosis. Straight, smooth baltoceratids with large, strongly eccentric or marginal, tubular or slightly expanded siphuncle (diameter more than $0.25 \%$ of shell diameter); connecting ring thin compared with Protocycloceras; septal spacing of orthoceridan aspect (i.e., two to three septa in a length comparable to conch diameter); septal necks orthochoanitic; endosiphuncular rod in apical parts of nearly mature specimens; cameral deposits mural, episeptal. (Compiled from Kröger et al. 2007)

\section{Cochlioceras? aff. roemeri Dzik, 1984}

Figures $7 \mathrm{~T}-\mathrm{U}$

1935 Orthoceras indéterminés Type A. - Thoral: 194, pl. 15, figs 1a-1b. Material. USTM-ACI 405 figured by Thoral (1935, pl. 15, figs 1a1b), six specimens (FSL 392183, 392188-89, 392226, 392232,

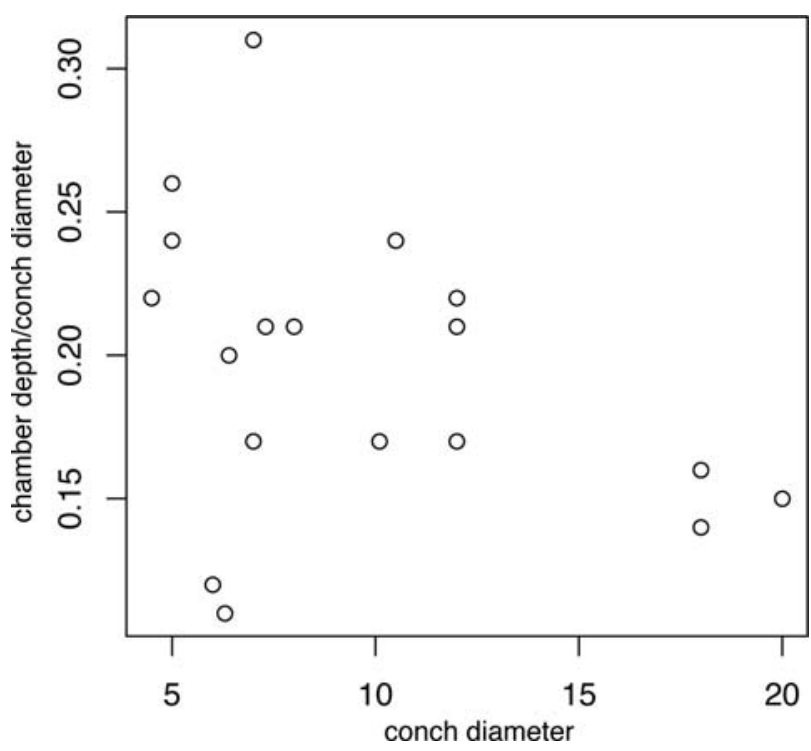

Figure 8. Diagram of conch diameter against relative chamber depth in Rioceras escandei (Thoral, 1935). Note the tendency of decreasing relative chamber depth with increasing conch diameter. 
392234) from the Asaphelina barroisi berardi + Taihungshania miqueli Subzone, St. Chinian Formation, late Tremadocian, north-east of the school of Prades-sur-Vernazobres, and three specimens from the Taihungshania miqueli acme Subzone, La Maurerie Formation, earliest Floian, Prades-sur-Vernazobres, Canto Cigale (FSL392182, 392190) and surroundings of Prades-sur-Vernazobres (FSL 392186), all Hérault, France.

Description. FSL 392183 consists of a portion of phragmocone, represented by a mould partly filled with sediment. The length of the fragment is $31 \mathrm{~mm}$, and it increases in diameter from $6 \mathrm{~mm}$ to $9.5 \mathrm{~mm}$ over this distance giving an angle of expansion of $6.5^{\circ}$. The conch surface is smooth, and the sutures straight and directly transverse. Three camerae occur in a distance equal to the phragmocone diameter. The siphuncle is tubular, with a diameter 0.3 that of the phragmocone. The ventral wall of the siphuncle is $1 \mathrm{~mm}$ distant from the phragmocone wall, or 0.1 of the distance across the diameter of the phragmocone. FSL 392190 with a maximum diameter of $9 \mathrm{~mm}$ has a tubular body-chamber $15 \mathrm{~mm}$ long.

Some variation is evident in the specimens included here. Of those specimens where the rate of expansion of the shell has been possible to measure, there appears to be a decrease in the apical angle with increasing conch diameter, with the most adoral portion of the shell approaching tubular in shape, but with the more apical portion of the shell expanding more rapidly. Septal depth ranges from 0.09 to 0.2 (mean $=0.15, n=4$ [including specimen figured by Thoral]). Cameral depth appears to be fairly consistent with a mean of 0.3 the phragmocone diameter ranging from a minimum of 0.27 to a maximum of 0.43 . The siphuncle diameter ranges from 0.17 (FSL 392234) to 0.31 (Thoral's figured specimen USTM-ACI 405) that of the phragmocone diameter. The average distance by which the ven-
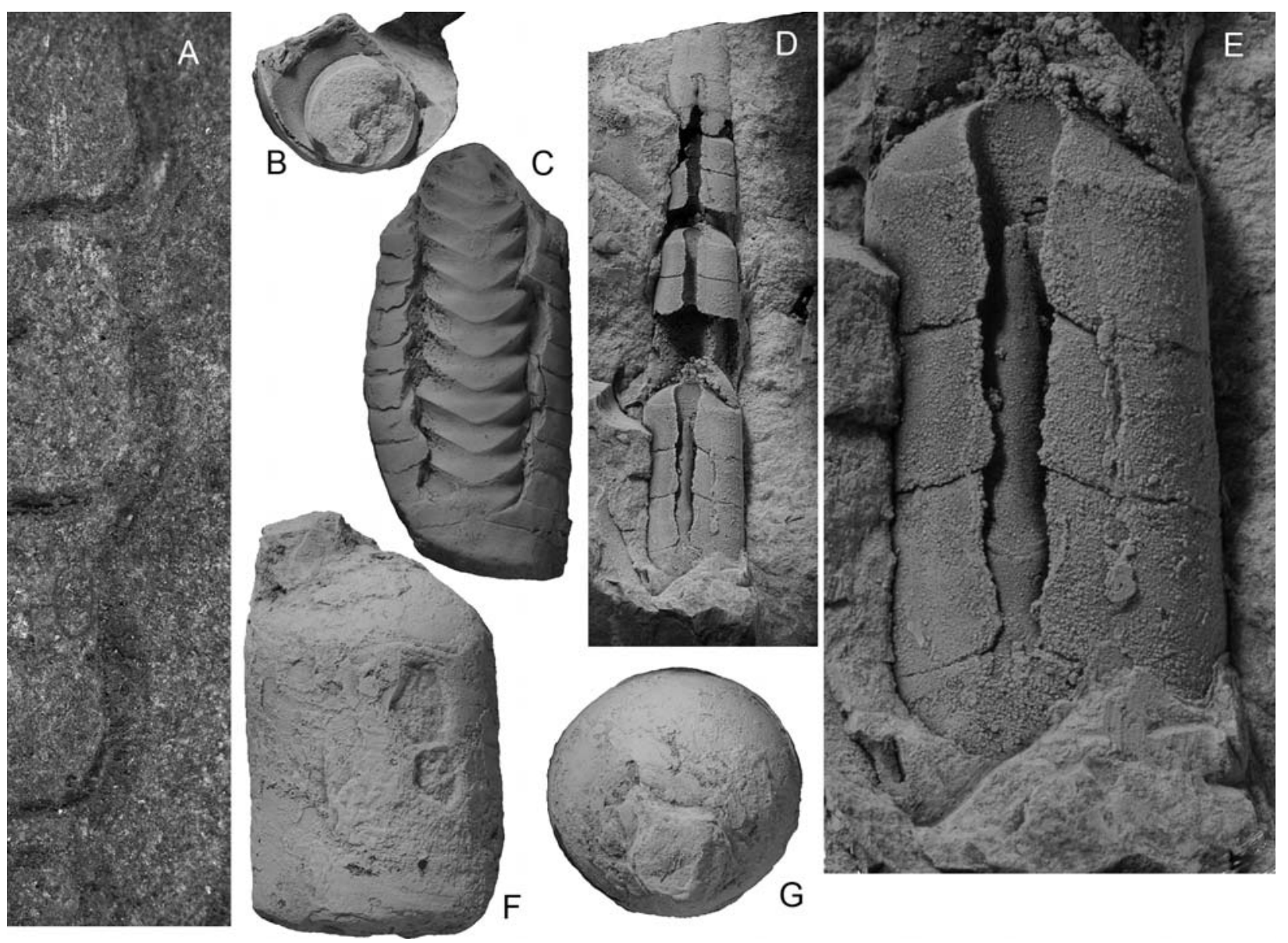

Figure 9. Details of Lobendoceras undulatum n. sp., and Thoraloceras bactroceroides n. sp. A-C. Lobendoceras undulatum $\mathrm{n}$. $\mathrm{sp}$. St. Chinian Formation. All Félines-Minervois, Hérault; A. FSL 392274. Section through siphuncle showing altered septa, septal necks and connecting rings and interpreted as subholochoanitic necks covered by connecting rings (see also Fig. 11 for interpretation. $\times 10$; B. FSL 392278. Septal view of phragmocone showing broad ventral siphuncle. $\times 1.25$; C. FSL 392273 . Ventral view of portion of siphuncle showing broad ventral siphuncle. $\times 1.0$; D-E. Thoraloceras bactroceroides $\mathrm{n}$. sp. St. Chinian Formation, Félines-Minervois, Hérault; D. FSL 392229. Ventral view of phragmocone deep camerae with the empty mould of a ventral siphuncle containing a 'spiess'-like sediment fill adorally. $\times 1.25$; E. FSL 392229. Detail of the 'spiess'-like sediment fill showing undulating surface of the structure. $\times 5.0 ; \mathbf{F}-\mathbf{G}$. Order, family, genus and species indeterminate. St. Chinian and La Maurerie formations. FSL 292269. Northeast of the school, Prades-sur-Vernazobre, Canto Cigale, Hérault; F. Lateral view of body-chamber (venter to left) showing large ventral siphuncle and traces of oblique growth lines on surface of mould. $\times 1.5$; G. Septal view of apical end of body-chamber (venter down). $\times 1.5$. 
tral wall of the siphuncle is separated from the wall of the phragmocone is 0.1 of the phragmocone diameter, but this varies from less than 0.1 to 0.15 (Fig. 9). Two of the specimens included are recorded as having siphuncles in contact with the phragmocone wall, and on this basis ought to be excluded here. However, it is possible that the siphuncle is slightly removed from the siphuncle wall in these specimens, and in both cases (Figs 7T-7U), it is difficult to elucidate the relationship of the siphuncle to the wall of the shell as it is difficult to see the ventral side of the siphuncle within the mould of the phragmocone.

In all specimens where the siphuncle is visible, it appears to be tubular. No information regarding the nature of the surface of the shell has been obtained from these specimens as all are internal moulds or replacements of the original internal structures of the phragmocone. Thoral $(1935,194)$ noted the presence of 'wide rings by narrow, shallow groves' in Orthoceras indéterminés Type A. The illustrated specimen may show some rather coarse transverse striae or ridges on the surface of the shell, but this is not conclusive.

Stratigraphic and geographic occurrences. Asaphelina barroisi berardi + Taihungshania miqueli Subzone, St. Chinian Formation, late Tremadocian to Taihungshania miqueli acme Subzone, La Maurerie Formation, early Floian, Montagne Noire, Hérault, France; Paroistodus originalis Zone, late Dapingian, of the lower Red Vaginatum Limestone, and from the Lasnamägian, late Darriwilian, from erratic boulders northern Poland (Dzik 1984).

Discussion. Cochlioceras roemeri is characterised by a rate of expansion apically of about $7^{\circ}$, decreasing adorally so that the adult portion of the shell is almost tubular. The cross-section of the shell is circular to slightly

\section{Given : relative siphuncular diameter}
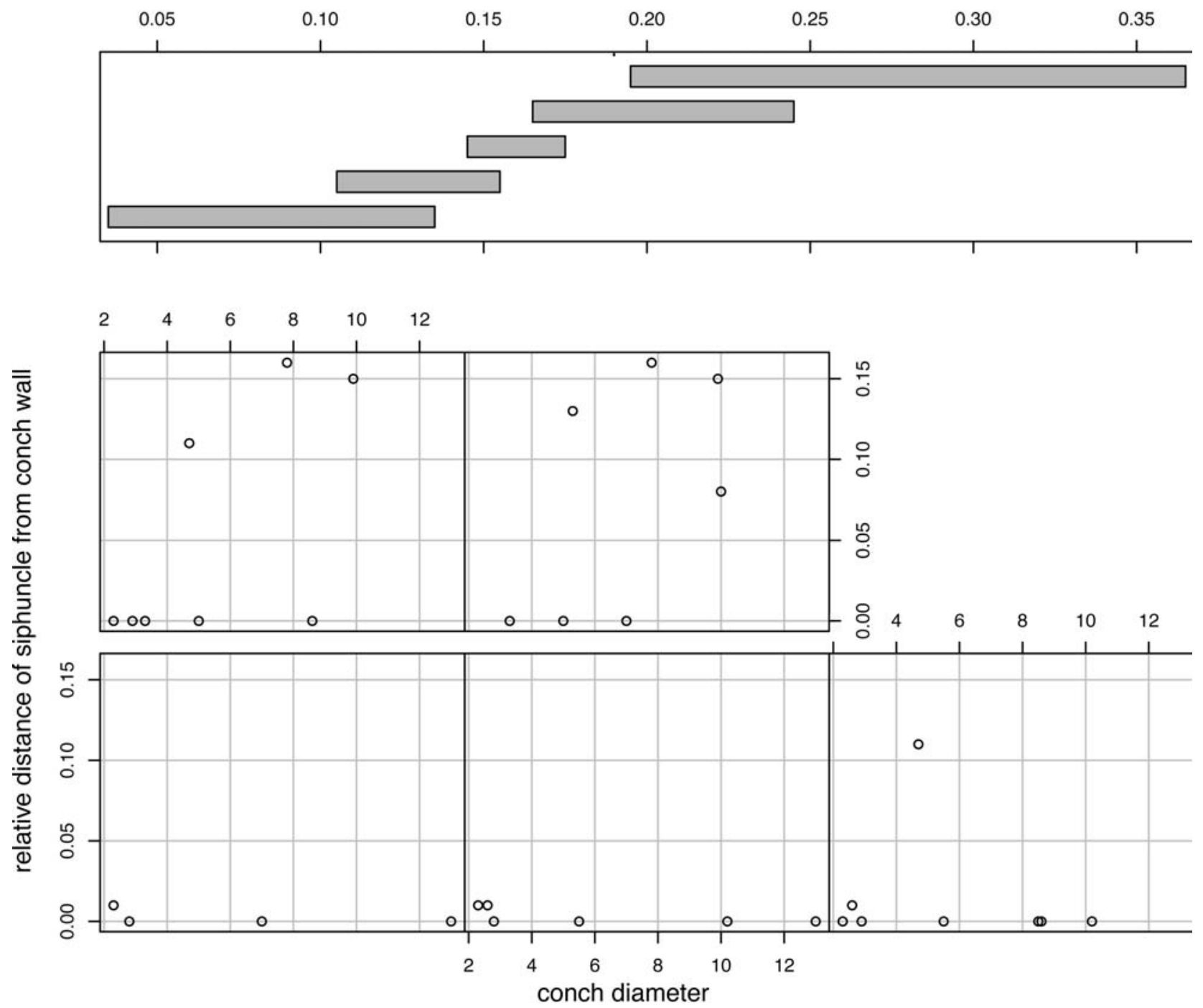

Figure 10. Diagrams of conch diameters against relative distance of siphuncle from conch wall of five fractions of relative siphuncular diameter in Bactroceras mourguesi (Thoral, 1935), Cochlioceras? aff. roemeri Dzik, 1984, and Thoraloceras bactroceroides n. sp. (conditional variables of each diagram as specified in the topbox). The diagrams show the clear morphological separation of specimens with marginal siphuncle and with siphuncle somewhat removed from conch wall in all fractions, and conch sizes. 
compressed with camerae of a depth 0.3 to 0.5 that of the phragmocone diameter. The diameter of the siphuncle is 0.3 that of the phragmocone whilst being slightly removed from the phragmocone wall. The connecting rings are tubular, and the septal necks orthochoanitic. In the type material of $C$. roemeri, an endosiphuncular rod is developed apically.

Of those species of Cochlioceras previously described, only $C$. roemeri possesses a siphuncle that is removed from the phragmocone wall. When disregarding the two cases with doubtful siphuncle position a clear separation between specimens of Bactroceras mourguense and the specimens described above is apparent by the position of the siphuncle (Fig. 10). Only some of the specimens described above have siphuncle diameters that approach that of $C$. roemeri, and several are narrower than those that might be expected for Cochlioceras in general. Thus the material is assigned to $C$. roemeri with some doubt. Additional, better-preserved material, yet to be found, may help to resolve this issue.

Order Dissidocerida Zhuravleva, 1964

Family Troedsonellidae Kobayashi, 1935

\section{Genus Thoraloceras n. gen.}

Derivation of name. Referring to Marcel Thoral (1900-1956), the pioneer in the Paleozoic Montagne Noire palaeontology.

Type species. Thoraloceras bactroceroides n. sp. from the late Tremadocian, Saint-Chinian Formation, Hérault, France.

Diagnosis. Slender, straight conchs with smooth shell; sutures directly transverse, widely spaced; septal necks orthochoanitic; siphuncle marginal with diameter of about 0.25 of conch cross section; siphuncular segments tubular; endosiphuncular deposits form endocones with central tip.

Species included. Type species only.

Discussion. See discussion of type species.

\section{Thoraloceras bactroceroides $\mathbf{n}$. sp.}

Figures 9D-E

Derivation of name. Refers to the similarity of this species with species of Bactroceras.

Holotype. Specimen FSL 392229.

Type locality and horizon. Euloma filacovi Zone, St. Chinian Formation, late Tremadocian, Félines-Minervois, Hérault, France.

Material. Three additional specimens from type horizon; FSL 392245 from Félines-Minervois, specimen FSL 392249 from the Asaphelina barroisi berardi + Taihungshania miqueli Subzone, St. Chinian Formation, late Tremadocian, North-East of the school of Prades-surVernazobres ; and one unnumbered specimen in the large nodule FSL 392293 from Prades-sur-Vernazobres.

Description. FSL 392229 is a portion of phragmocone $40 \mathrm{~mm}$ long, with an apical angle of $6.4^{\circ}$ and a median diameter of $6.5 \mathrm{~mm}$. The conch surface is smooth and the cross-section circular. The depth of the camerae is 0.5 that of the corresponding phragmocone diameter.
At the adoral end of the specimen, the siphuncle is marginal in position with its wall almost in contact with the wall of the phragmocone. Its diameter is 0.26 that of the phragmocone. The connecting rings are tubular and the joins between the siphuncular segments are flush, indicating the presence of short, orthochoanitic septal necks. At the apical end of the fragment the sediment infilling the siphuncle from the adoral end tapers to form a 'spiess'-like structure $8 \mathrm{~mm}$ in length. This sediment fill is truncated apically, but clearly lies at the centre of the siphuncle. The general shape of the sediment fill at the point of the truncation suggests that it might have continued apically in the form of a narrow rod. The tapering of this structure is not constant throughout its length and it appears to undergo more rapid contraction in the vicinity of the septal necks. The sediment fill is interpreted as the mould of an endosiphuncular deposit forming a lining that accretes adorally to form endocone-like structures, but probably left a central tube through the deposits. No cameral deposits are evident.

None of the other specimens provide any evidence for the presence of endosiphuncular deposits. All three specimens consist of portions of phragmocone that are otherwise similar in their characters and dimensions to FSL 392229.

Discussion. Comprising slender straight shells with widely spaced chambers and marginal tubular siphuncles, the specimens assigned to Thoraloceras bactroceroides n. sp. are very similar to Bactroceras mourguesi (Thoral, 1935). They differ from the former in having (a) a wider siphuncular diameter; and (b) in the case of FSL 392229 the traces of the mould of endosiphuncular deposits, resembling those of the Troedssonellidae are present.

Of the 19 specimens measured (Fig. 11) which possess smooth longiconic shells combined with a tubular, marginal siphuncle, the frequency distribution of the relative diameter of the siphuncle shows a major peak at $0.10-0.15$ and a subordinate peak at $0.25-0.30$. Whilst the subordinate peak may be an artifact of the limited sample size, one specimen of this group, FSL 392229 possesses endosiphuncular deposits. Such deposits are not known in Bactroceras, and are more characteristic of a troedssonellid. The four specimens that form the subordinate group may therefore be readily separated from B. mourguesi on the grounds of their relative siphuncle diameter, and the assumption that three of them, although lacking any endosiphuncular deposits, are likely to belong to the same taxon.

Although the presence of endosiphuncular deposits in one of these specimens indicates that their assignment to the new genus Thoraloceras is justified, without additional comparative material it is difficult to be completely confident in regard to their allocation to the Troedssonellidae as indicated by the queried assignment (above). Thoraloceras is distinctly different from other troedssonellids such as Buttsoceras Ulrich \& Foerste, 


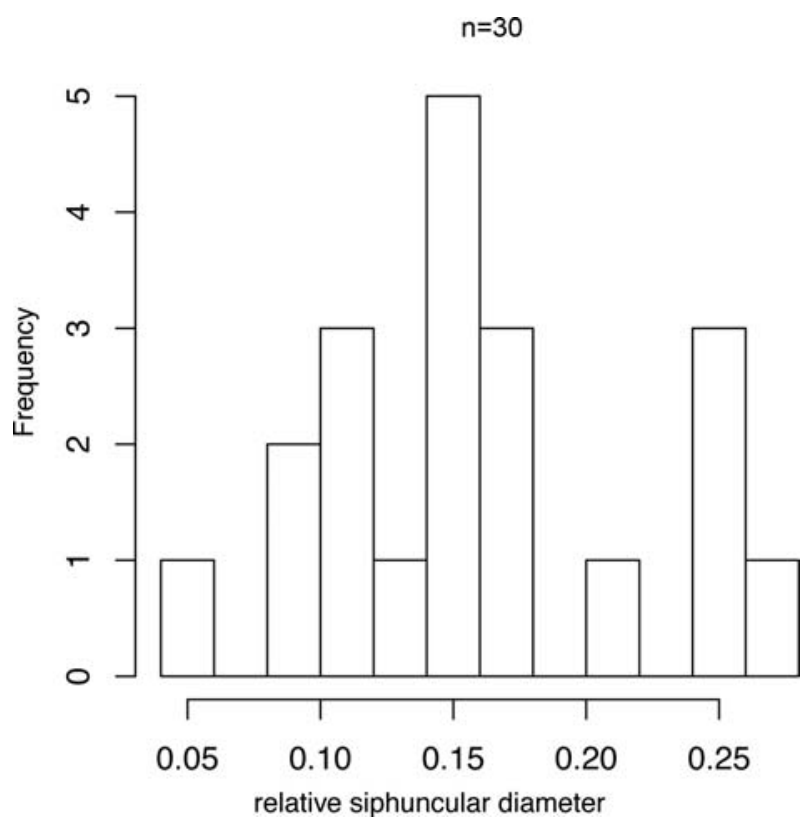

Figure 11. Frequency distribution of relative siphuncular size in Bactroceras mouguesi (Thoral, 1935) and Thoraloceras bactroceroides $\mathrm{n}$. sp. Note the bimodal distribution pattern.

1936 in its possession of a marginally positioned siphuncle as opposed to a central siphuncle and the apparent lack of any cameral deposits which are often well-developed in Buttsoceras.

Family Protocameroceratidae Kobayashi, 1937 Order Endocerida Teichert, 1933

\section{Genus Lobendoceras Teichert \& Glenister, 1954}

Type species. Lobendoceras emanuelense Teichert \& Glenister, 1954. By original designation. Early Ordovician, Emanuel Formation of the Prices Creek Group, Emanuel Creek, Kimberley Division, Western Australia.

Diagnosis. Slender orthocones with circular section. Camerae shallow. Sutures with broad and deep ventral lobe. Moderate to large circular siphuncle in contact with ventral wall of phragmocone. Septal necks subholochoanitic and connecting rings thick. Endosiphuncular deposits as yet unknown. (After Teichert 1964).

\section{Lobendoceras undulatum n. sp.}

Figures 7O, P, V, W; 8A-C; 12

1935 Orthoceras sp.III. groupe de $O$. duplex Wahlenberg. - Thoral: 193, pl. 17, figs 2-7.

Derivation of name. Referring to the combination of broad lobes and saddles forming the sutures.

Holotype. Specimen FSL 392274.

Diagnosis. Lobendoceras with poorly developed ventral lobe combined with weak dorsoventral saddles and a shallow dorsal lobe.

Type locality and horizon. The specimens described by Thoral (1935) come from the basal Faunizone $\mathrm{H}=$ Taihungshania miqueli acme Subzone, of the La Maurerie Formation in the vicinity of St. Chinian and Prades sur Vernazobres, Hérault.
Material. Eleven specimens (FSL 392270-80) from the Euloma filacovi Zone, St. Chinian Formation, late Tremadocian, Félines-Minervois, Hérault, and one specimen (FSL 329281) from the Asaphelina barroisi berardi + Taihungshania miqueli Subzone, St. Chinian Formation, late Tremadocian, Prades-sur-Vernazobres, North-East of the school, Hérault.

Description. The material consists almost entirely of portions of the internal moulds of phragmocones, a few of which retain part of the body-chamber. Although the siphuncle remains intact in some individuals, the septa appear to have been lost in all specimens.

The rate of expansion of the phragmocones ranges from 0.5 degrees to 3.5 degrees. The largest specimen reaches at least $25 \mathrm{~mm}$ in diameter, but no specimen is less than $10.5 \mathrm{~mm}$ in diameter. The cross-section of the phragmocone is circular to very slightly depressed. Cameral depth ranges from 12 to $26 \%$ of the phragmocone diameter, and on the basis of several specimens (Fig. 13) would appear to decrease with the growth of the shell. The sutures area best seen in FSL 392274 and FSL 392277, where they are almost transverse, but slightly inclined dorsally towards the aperture, whilst a broad and shallow ventral lobe is combined with broad dorsoventral saddles and a shallow dorsal lobe. By inference from the inclination of the septal necks on the siphuncle preserved in FSL 392270, the septa are estimated to have had a depth about 0.30 that of the phrag-

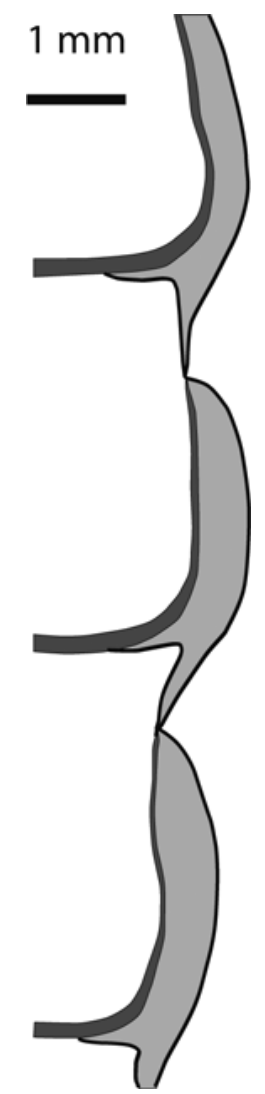

Figure 12. Interpretation of the structure of siphuncle in $\mathrm{Lo}$ bendoceras undulatum n. sp. FSL 392274, St. Chinian Formation, Félines-Minervois, Hérault, showing subholochoanitic septal necks and thickened connecting rings coating the septal necks. 


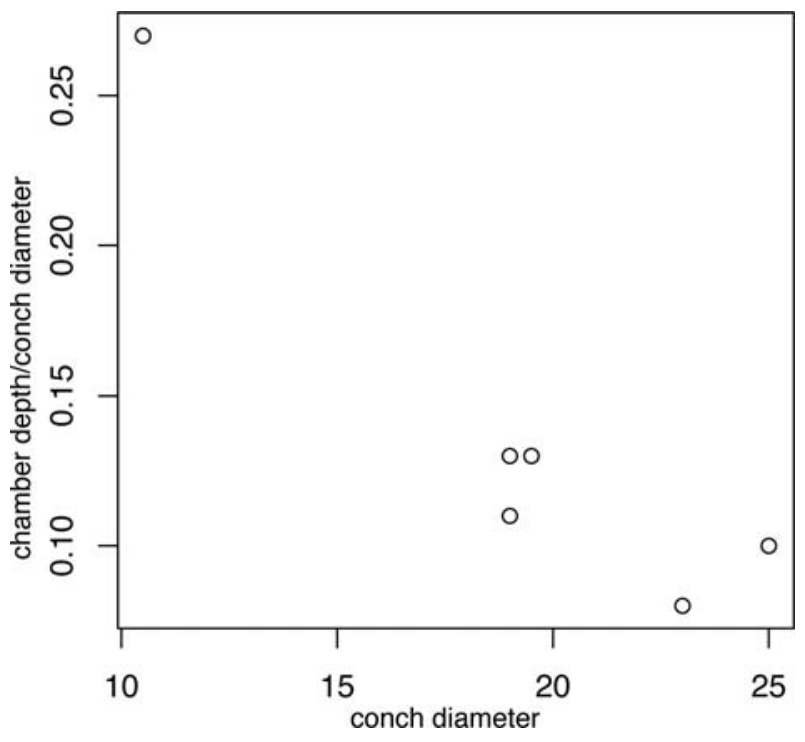

Figure 13. Diagram of conch diameter against relative chamber depth in Lobendoceras undulatum sp. nov. Note the tendency of decreasing relative chamber depth with increasing conch diameter.

mocone diameter. The siphuncle is marginal in position and large, ranging in relative diameter from 0.30 to 0.60 that of the dorsoventral diameter of the phragmocone.

A constriction is present on the phragmocone of FSL 392277. The plane of the constriction lies at about 45 degrees to the conch axis, directed so that it is inclined towards the dorsum in an apertural direction. The phragmocone of this specimen is $24 \mathrm{~mm}$ in diameter, and the constriction reduces this diameter to $22 \mathrm{~mm}$. On the ventral side of the phragmocone, the width of the constriction (parallel to the conch axis) is $6 \mathrm{~mm}$, and on the dorsal side $16 \mathrm{~mm}$.

Moulds of the siphuncle are seen in several specimens (Figs 7O, P, 8C). The moulds are markedly constricted between the septal foraminae, and would appear to indicate that the connecting rings were concave in shape. However, a dorsoventral sagittal section through FSL 392274 reveals the presence of poorly preserved septal necks and connecting rings on the dorsal side of the siphuncle (Fig. 12). These show that the wall of the siphuncle is at a minimum thickness, not at the position of the septal foramen, but about $0.6 \mathrm{~mm}$ further in an apertural direction. This suggests that the connecting ring does not extend the full length of the siphonal segment and that the septal necks are subholochoanitic or nearly subholochoanitic, so that the connecting ring is attached to the tip of the next septal neck toward the aperture, but lines the surface of the septal neck of the previous segment.

Nothing is known of the sculpture of the surface of the shell.

Discussion. In their possession of a very large siphuncle combined with the presence of what are probably very long subholochoanitic septal necks, these specimens are entirely distinct from any of the cephalopod taxa known from the La Maurerie Formation.
Despite the lack of any evidence for the presence of endocones in the material under description, this material is assigned to the Proterocameroceratidae on the basis of their similarity to other taxa assigned to the family. This material is assigned to Lobendoceras on the basis of its general similarity to the type species (which also lacked evidence for the presence of endocones in the type material), despite the less pronounced ventral lobes of the sutures in L. undulatum. Although L. emanuelense is only known from the holotype and a paratype, in terms of the cameral depth and relative diameter of the siphuncle, there is little distinction between this species and L. undulatum. In discussing the relationships of the Early Ordovician Protocyptendoceras Cecioni, 1965 from the Eastern Cordillera of northwestern Argentina to other members of the Protocameroceratidae, Cichowolski (2009) noted the similarity of the genus to Anthoceras Teichert \& Glenister, 1954, whilst noting the possession of an annulate shell in the latter taxon. Cichowolski (2009) distinguished Lobendoceras from Protocyptendoceras on the grounds that the latter genus is generally smaller than Lobendoceras and more depressed in section. Whilst there is a clear difference between the shapes of the ventral lobes in each taxon, the data provided by Cicholowski (2009, fig. 1) illustrate that there is little overall difference between P. fuenzalidae Cecioni, L. emanualense and L. undulatum in terms of the shape of the conch crosssection. Moreover, comparison of these three taxa in relation to cameral depth and relative siphuncle diameter suggests that Protocyptendoceras is very similar to Lobendoceras, and it is possible that the differences in the populations could be either a function of taphonomic bias or a consequence of an evolutionary increase in the overall size of Protocyptendoceras or vice versa. The development of a broad and deep ventral lobe may be the consequence of the siphuncle becoming more depressed in section and developing a greater surface of contact with the wall of the siphuncle, but again, the reverse might be equally true. However, there appears be a difference in the depth of the septa between the genera, although the estimation of septal depth in the material described here is based upon a projection of the trend of the septal foramen across the siphuncle. Comparison of the same features suggest that these Lobendoceras and Protocyptendoceras are more similar to each other than either is to Anthoceras and a close relationship if not synonymy at the generic level is possible. No account is taken here of the significance or otherwise of the constriction of the phragmocone seen in FSL 392277. Additional material might suggest whether this feature is of taxonomic significance.

\section{Order, family, genus and species indeterminate}

Figures 9F, G

1935 Orthoceras indéterminés Type A. - Thoral: 194, pl. 15, figs 1a, $1 \mathrm{~b}$. 
Material. USTM-ACI 405, figured (194, pl. 15, figs 1a, 1b), from an unspecified horizon (likely to be from the basal Faunizone $\mathrm{H}=$ Taihungshania miqueli acme Subzone, of the La Maurerie Formation) in the vicinity of St. Chinian, Hérault. FSL 392269 from the Asaphelina barroisi berardi + Taihungshania miqueli Subzone, St. Chinian Fm., late Tremadocian, North-East of the school at Prades-sur-Vernazobres, Hérault, and FSL 392284 from the Taihungshania miqueli acme Subzone, La Maurerie Formation, early Floian Prades-sur-Vernazobres, La Maurerie, Hérault.

Description. The specimen figured by Thoral (1935, pl. 15, figs $1 \mathrm{a}, \mathrm{b})$ was described as consisting of a body-chamber $47 \mathrm{~mm}$ long, increasing in diameter from $15.5 \mathrm{~mm}$ to $17.0 \mathrm{~mm}$, giving a rate of expansion of 1.8 degrees. The shell surface consists of broad rings (striae) separated by narrow grooves. The disposition of the striae relative to the conch axis was not stated and cannot be determined from the illustration. The siphuncle is marginal in position and $5.5 \mathrm{~mm}$ in diameter or 0.35 that of the dorsoventral diameter of the conch. Both the specimens in the University of Lyon collections consist of aperturally incomplete body-chambers with a circular or very slightly depressed cross-section and a septal depth between 0.30 and 0.33 that of the conch diameter. The rate of expansion of the bodychamber in FSL 392269 is 2 degrees. The suture at the base of the body-chamber is almost directly transverse, but with a broad and shallow lobe over the venter. The siphuncle, which is removed from the wall of the shell by $0.5 \mathrm{~mm}$, is circular in section and ranges from 6.5 to $7.0 \mathrm{~mm}$ in diameter or around 0.35 that of the conch diameter. The siphuncle is otherwise so poorly preserved that nothing can be made of its form and structure of the septal neck or connecting ring.

The surface of the shell in FSL 392269 possesses a sculpture in the form of striae with a density of between 2 and 3 per $\mathrm{mm}$. These are obliquely inclined dorsally towards the aperture, but on the dorsolateral surface they appear to reflex and, and although not preserved, a shallow sinus may be present.

Discussion. FSL 392269 and FSL 392284 are similar to the specimen figured by Thoral in their overall size and the relative diameter of the siphuncle. The septum of the specimen figured by Thoral is shallower than in the two other specimens, whilst the shell sculpture observed in FSL 392269 may differ from that of the specimen described by Thoral in terms of its disposition. Despite the differences noted, it seems probable that these specimens belong to same taxon. Whilst being indeterminate, within the assemblage described above, these specimens appear closest in their surviving features to Lobendoceras and Cochlioceras.

\section{Acknowledgements}

We are grateful to Bertrand Lefebvre (Lyon, France) and Daniel Vizcaïno (Carcassonne, France) who provided us with much valuable information and helped to identify the stratigraphy of the specimens. We are grateful to Bertrand Lefebvre and Abel Prieur (Lyon, France) for their hospitality and the support they provided whilst we were working at the FSL. We thank Bertrand Lefebvre, Kathleen Histon (Geological Survey of Austria) and Štěpán Manda (Czech Geological Survey) for their helpful and constructive reviews that have helped to improve this paper.

\section{References}

Aceñolaza, F. G. \& Beresi, M. S. 2002. Ordovician nautiloids of Argentina. In Aceñolaza, F. G. (ed.). Aspects of the Ordovician System in Argentina. - Serie Correlación Geologica 16: 107-120.

Aceñolaza, F. G., Durand, F. \& Diaz Taddei, R. 1977. Nautiloideos ordovicicos de la Precordillera Argentina. Fauna de Huaco. Provincia de San Juan. - Acta Geologica Lilloana 13: 219-244.

Agassiz, L. 1847. An introduction to the study of natural history, in a series of lectures delivered in the hall of the College of Physicians and Surgeons. New York.

Álvaro, J. J., González-Gómez, C. \& Vizcaïno, D. 2003. Paleogeographic patterns of the Cambrian - Ordovician transition in the southern Montagne Noire (France) : preliminary results. - Bulletin de la Société Géologique de France 174: 217-225.

Astini, R. A. 2003. The Ordovician Proto-Andean Basins. In Benedetto, J. L. (ed.). Ordovician fossils of Argentina. Secretaría de Ciencia y Tecnología, Universidad Nacional de Córdoba: pp. 1-74.

Balashov, Z. G. 1961. Ordovician nautiloids of the Siberian Platform. Izdatelstvo Leningrad University, Leningrad (St. Petersburg) [In Russian].

Barrande, J. 1867. Systême Silurien du centre de la Boheme. Part 2. Céphalopodes, texte: part 1. Published privately, Prague.

Billings, E. 1859. Fossils of the calciferous sandrock, including those of a deposit of white limestone at Mingan, supposed to belong to the formation. - Canadian Naturalist and Geologist 4: 345-367.

Bogolepova, O. K. 1995. Lower Silurian cephalopod limestones from the Mojero River section (eastern Siberia, Russia) and their paleogeographic relationships. - Jahrbuch der Geologischen Bundesanstalt 138: $155-160$.

Bogolepova, O. K. 1998. Silurian cephalopod beds from North Asia. In Landing, E. \& Johnson, M. E. (eds). Siluran cycles. Linkages of dynamic stratigraphy with atmospheric, oceanic, and tectonic changes. - New York State Museum Bulletin 491: 199-207.

Bogolepova, O. K. \& Holland, C. H. 1995. Concentrations of Silurian nautiloid cephalopods from Russia and Kazakhstan. - Acta Palaeontologica Polonica 40: 429-440.

Boyer, F. \& Guiraud, R. 1964. Observations nouvelles sur le passage du Cambrien à l'Ordovicien dans la Montagne Noire. - Bulletin de la Société Géologique de France 135: 515-522.

Brøgger, W. C. 1882. Die silurischen Etagen 2 und 3 im Kristianiagebiet und auf Eker, ihre Gliederung, Fossilien, Schichtenstörungen und Contactmetamorphosen. Universitets -Program, 2. Semester. A. W. Brøgger, Kristiana.

Cecioni, G. 1953. Contribucion al conocimiento de los Nautiloideoseopaleozoicos Argentinos. Parte I: Protocycloceratidae - Cyclostomiceratidae. - Boletin del Museo Nacional de Historia Natural 26: $56-110$.

Cecioni, G. 1965. Contribucion al conocimiento de los Nautiloideoseopaleozoicos Argentinos. Parte II: Robsonoceratidae, Ellesmeroceratidae, Proterocameroceratidae, Baltoceratidae. - Boletin del Museo Nacional de Historia Natural 29: 1-24.

Cecioni, G. \& Flower, R. H. 1985. Bathmoceratidae (Nautiloideos, Ordovicico) de Sud America. - Neues Jahrbuch für Geologie und Paläontologie. Abhandlung 170: 243-357.

Chen, Jun-yuan 1976. Advances in the Ordovician stratigraphy of North China with a brief description of nautiloid fossils. - Acta Palaeontologica Sinica 15: 55-74 [In Chinese with English abstract].

Chen, Jun-yuan \& Zou Xi-peng 1984. Ordovician cephalopods from the Ordos area, China. - Memoirs Nanjing Institute of Geology and Palaeontology 20: 33-111 [In Chinese]. 
Chen, Jun-yuan \& Teichert, C. 1987. The Ordovician cephalopod suborder Cyrtocerinina (Order Ellesmerocerida). - Palaeontologia Cathayana 3: 135-186.

Cichowolski, M. 2009. A review of the endocerid cephalopod Protocyptendoceras from the Floian (Lower Ordovician) of the Eastern Cordillera, Argentina. - Acta Palaeontologica Polonica 54: 99109.

Cichowolski, M. \& Vaccari, N. E. 2010. The oldest record of Eothinoceratidae (Ellesmerocerida, Nautiloidea): Middle Tremadocian of the Cordillera Oriental, NW Argentina. - Geological Journal. DOI: $10.1002 /$ gj. 1250 .

Courtessole, R., Pillet, J. \& Vizcaïno, D. 1981. Nouvelles données sur la biostratigraphie de l'Ordovicien inférieur de la Montagne Noire. Révision des Taihungshaniidae, de Megistaspis (Ekeraspis) et d'Asaphopsoides (Trilobites). - Mémoires de la Société d'Etudes Scientifiques de l'Aude: 1-32.

Courtessole, R., Marek, L., Pillet, R., Ubaghs, G. \& Vizcaïno, D. 1983. Calymenina, Echinodermata et Hyolitha de l'Ordovicien inférieur de la Montagne Noire (France meridionale). - Mémoires de la Société d'Etudes Scientifiques de l'Aude: 1-62.

Courtessole, R., Pillet, J., Vizcaïno, D. \& Eschard. R. 1985. Étude biostratigraphique et $\mathrm{s}$ sédimentologique des formations arénacées de l'Arenigien du Saint-Chinianais oriental (Hérault) versant sud de la Montagne Noire (France méridionale). - Mémoires de la Société d'Etudes Scientifiques de l'Aude: 1-99.

Courtessole, R., Henry, J. L. \& Vizcaïno, D. 1991. Quelques Calymenidae (Trilobita) de l'Ordovicien inférieur (Arenig) de la Montagne Noire, France: systématique, évolution et paléoenvironnements. - Palaeontographica A 218: 1-15.

Cuvier, G. L. C. F. D. 1797. Tableau élémentaire de l'histoire des animaux. Deterville, Paris.

Dean, W. T. 1966. The Lower Ordovician stratigraphy and trilobites of the Landeyran Valley and the neighbouring district of the Montagne Noire, south-western France. - Bulletin of the British Museum (Natural History), Geology 12: 245-353.

Dewitz, H. 1879. Das Verwachsungsband der Vaginaten. - Sitzungsberichte der Gesellschaft der naturforschenden Freunde zu Berlin 1879 (9): 143-146.

Demange, M. 2001. Tectono-stratigraphic setting of the southern slope nappes of the Montagne Noire. - Annales de la Société géologique du Nord 8: 191-200.

Dzik, J. 1984. Phylogeny of the Nautiloidea. - Palaeontologica Polonica 45: 1-219.

Eichwald, E. 1860. Lethaea Rossica ou Paléontologie de la Russie. Volume 1: Seconde section de l'ancienne période. E. Schweizerbart, Stuttgart.

Endo, R. 1932. The Canadian and Ordovician Formations and Fossils of South Manchuria. - Bulletin of the United States National Museum 164: 1-152.

Evans, D. H. 1988. Cephalopods from the Ordovician of England and Wales. Unpublished Ph.D. Thesis. University of Wales.

Evans, D. H. 2005 (for 2004). The Lower and Middle Ordovician cephalopod faunas of England and Wales. - Monograph of the Palaeontographical Society, London 158: 1-81.

Evans, D. H. 2007. A Middle Ordovician cephalopod fauna from Cuzco Province, southern Perú and its palaeobiogeographic significance. - Geological Journal 42: 25-36.

Ferretti, A. \& Křiž, J. 1995. Cephalopod limestone biofacies in the Silurian of the Prague Basin, Bohemia. - Palaios 10: 240-253.

Flower, R. H. 1962. Revision of Buttsoceras. - New Mexico Bureau of Mines and Mineral Resources, Memoir 10: 1-17.

Flower, R. H. 1964. The nautiloid order Ellesmeroceratida (Cephalopoda). - New Mexico Bureau of Mines and Mineral Resources, Memoir 12: 1-234.

Flower, R. H. 1968. Cephalopods from the Tiñu Formation, Oaxaca State, Mexico. - Journal of Paleontology 42: 904-810.

Flower, R. H. \& Kummel, B. 1950. Classification of the Nautiloidea. Journal of Paleontology 24: 604-615.
Foerste, A. F. 1921. Notes on Arctic Ordovician and Silurian cephalopods. - Denison University Bulletin, Journal of the Scientific Laboratories 19: 247-306.

Foerste, A. F. 1925. Notes on cephalopod genera; chiefly coiled Silurian forms. - Denison University Bulletin, Journal of the Scientific Laboratories 21: 1-70.

Foerste, A. F. 1926. Actinosiphonate, Trochoceroid and other cephalopods. - Denison University Bulletin, Journal of the Scientific Laboratories 21: 285-383.

Fortey, R. A. \& Owens, R. M. 1987. The Arenig Series in South Wales: Stratigraphy and Palaeontology. - Bulletin of the British Museum (Natural History) Geology 41: 69-307.

Glenister, B. F. 1952. Ordovician nautiloids from New South Wales. Australian Journal of Science 15: 89-91.

Gnoli, M. \& Pillola, G. L. 2002. The oldest nautiloid cephalopod of Sardinia: Cameroceras cf. vertebrale (Eichwald, 1860) from the Arenig (Early Ordovician) of Tacconis (South East Sardinia) and remarks on the associated biota. - Neues Jahrbuch für Geologie und Paläontologie, Monatshefte 2002 (1): 19-26.

Harrington, H. J. 1937. On some Ordovician fossils from northern Argentina. - Geological Magazine 74: 97-134.

Hewitt, R. A. \& Westermann, G. E. G. 1996. Post-mortem behaviour of Early Palaeozoic nautiloids and paleobathymetry. - Paläontologische Zeitschrift 70: 405-424.

Holm, G. 1898. Palaeontologiska notiser II: Om ett par Bactrites-liknade Untersiluriska Orthocera-former. - Geologiska Föreningens i Stockholm Förhandingar 20: 354-360.

Hook, S. C. \& Flower, R. H. 1977. Late Canadian (Zones J, K) cephalopod faunas from the southwestern United States. - New Mexico Bureau of Mines and Mineral Resources, Memoir 32: 1-101.

King, A. H. 1999. A review of the cyclostomiceratid nautiloids, including new taxa from the Lower Ordovician of Öland, Sweden. Palaeontology 41: 335-347.

Kobayashi, T. 1935. Restudy on Manchuroceras, with a brief note on the classification of endoceroids. - Journal of the Geological Society of Japan 42: 736-752.

Kobayashi, T. 1937. Contribution to the study of the apical end of the Ordovician nautiloid. - Japanese Journal of Geology and Geography 14: $1-21$.

Kröger, B. 2008. A new genus of middle Tremadocian orthoceratoids and the Early Ordovician origin of orthoceratoid cephalopods. Acta Palaeontologica Polonica 53: 754-759.

Kröger, B., Beresi, M. S. \& Landing, E. 2007. Early orthoceratoid cephalopods from the Argentine Precordillera (Lower-Middle Ordovician). - Journal of Paleontology 81: 1266-1283.

Kröger, B. \& Landing, E. 2008. Onset of the Ordovician cephalopod radiation - evidence from the Rochdale Formation (middle Early Ordovician, Stairsian) in eastern New York. - Geological Magazine 145: 490-520.

Kröger, B. \& Landing, E. 2009. Cephalopods and palaeoenvironments of the Fort Cassin Formation (upper Lower Ordovician), eastern New York and adjacent Vermont. - Journal of Palaeontology 83: 664-693.

Kröger, B. Servais, T. \& Zhang, Y. 2009. The origin and initial rise of pelagic cephalopods in the Ordovician. - PLoS ONE 4 (9): e7262. doi:10.1371/journal.pone.0007262

Kuhn, O. 1940. Paläozoologie in Tabellen. G. Fischer, Jena.

Lai, Caigen 1985. Cephalopods. In Institute of Geology and Mineral Resources (Ed.): Palaeontological Atlas of North China. 1. Palaeozoic volume. Geological Publishing House, Beijing: 731 p. [in Chinese].

Landing, E., Westrop, S. R. \& Keppie, J. D. 2007. Terminal Cambrian and lowest Ordovician succession of Mexican West Gondwana: biotas and sequence stratigraphy of the Tiñu Formation. Geological Magazine 144: 909-936.

Loi, A. \& Dabard, M.-P., 2002. Controls of sea level fluctuations on the formation of Ordovician siliceous nodules in terrigenous offshore environments. - Sedimentary Geology 153: 65-84. 
Marek, J., Weber, B., Schönian, F., Egenhoff, S. O. \& Erdtmann, B. D. 2000. Arenig cephalopods from southern Bolivia. In Cockle, P., Wilson, G. A., Brock, G. A., Engelbretsen, M. J., Simpson, A. \& Winchester-Seeto, T. (eds). Palaeontology Down-Under 2000. Geological Society of Australia, Abstracts 61: 56-57.

Miquel, J. 1912. Nouvel essai sur la géologie des terrains primaires du département de l'Hérault. Classification des terrains siluriens. Bulletin de la Société d'Etudes des Sciences Naturelles de Béziers 34: 1-48.

Murchison, R. I. 1839. The Silurian System founded on geological researches in the counties of Salop, Montgomery, Carmarthen, Brecon, Pembroke, Monmouth, Gloucester, Worcester, and Stafford: with descriptions of the coal-fields and overlying formations. John Murray, London.

Noffke, N. \& Nitsch, E. 1994. Sedimentology of Lower Ordovician clastic shelf deposits, Montagne Noire (France). - Géologie de la France 4: 3-19.

Radley, J. D. 2008. Seafloor erosion and sea-level change: early Jurassic Blue Lias Formation of central England. - Palaeogeography, Palaeoclimatology, Palaeoecology 270: 287-294.

Ramsay, A. C. 1866. The Geology of North Wales, with an appendix on the fossils by J. W. Salter. - Memoir of the Geological Survey of Great Britain 3: 1-381.

Teichert, C. 1933. Der Bau der actinoceroiden Cephalopoden. - Palaeontographica Abteilung A 78: 111-230.

Teichert, C. 1964. Endoceratoidea. In Moore, R. C. (ed.). Treatise on invertebrate paleontology. Part K. Mollusca 3, Cephalopoda, General features, Endoceratoidea, Actonoceratoidea, Nautiloidea, Bactritoidea. Geological Society of America and University of Kansas Press, Boulder, Colorado and Lawrence, Kansas: pp. 160-189.

Teichert, C. \& Glenister, B. F. 1952. Fossil Nautiloid faunas from Australia. - Journal of Paleontology 26: 730-752.

Teichert, C. \& Glenister, B. F. 1954. Early Ordovician cephalopod fauna from southwestern Australia. - Bulletins of American Paleontology 35: 1-113.

Thoral, M. 1935. Contribution à l'étude paléontologique de l'Ordovicien inférieur de la Montagne Noire et révision sommaire de la faune Cambrienne de la Montagne Noire. Imprimerie de la Charité, Montpellier.

Thoral, M. 1946. Cycles géologiques et formations nodulifères de la Montagne Noire. - Nouvelles Archives du Muséum d'Histoire Naturelle de Lyon 1: 1-103.

Tortello, M. F., Vizcaïno, D. \& Álvaro, J. J. 2006. Early Ordovician agnostoid trilobites from the Southern Montagne Noire, France. Journal of Paleontology 80: 477-495.

Ubaghs, G. 1969. Aethocrinus moorei Ubaghs, n. gen., n. sp., le plus ancien crinoïde dicyclique connu. - University of Kansas Paleontological Contributions 38: 1-25.

Ubaghs, G. 1970 (Dated 1969). Les échinodermes "Carpoïdes" de l'Ordovicien Inférieur de la Montagne Noire (France). - Cahiers de Paléontologie, Editions du CNRS 1969: 1-112.

Ulrich, E. O. 1936. New genera of Ozarkian and Canadian cephalopods. - Denison University Bulletin, Journal of the Scientific Laboratories 30: 259-290.

Ulrich, E. O. \& Foerste, A. F. 1936. New Genera of Ozarkian and Canadian Cephalopods. - Journal of the Scientific Laboratories of Denison University 30: 259-290.
Ulrich, E. O., Foerste, A. F. \& Miller, A. K. 1943. Ozarkian and Canadian cephalopods. Part III: Brevicones. - Geological Society of America Special Papers 49: 1-240.

Ulrich, E. O., Foerste, A. F., Miller, A. K. \& Unklesbay, A. G. 1944. Ozarkian and Canadian cephalopods. Part III: Longicones and summary. - Geological Society of America Special Papers 58: $1-$ 226.

Vizcaïno, D. \& Álvaro, J. J. 2003. Adequacy of the Early Ordovician trilobite record in the southern Montagne Noire (France): biases for biodiversity documentation. - Transactions of the Royal Society of Edinburgh, Earth Science 93: 393-401.

Vizcaïno, D., Álvaro, J. J. \& Lefebvre, B. 2001. The Lower Ordovician of the southern Montagne Noire. - Annales de la Société géologique du Nord 8: 213-220.

Vizcaïno, D. \& Lefebvre, B. 1999. Les échinodermes du Paléozoïque inférieur de la Montagne Noire: biostratigraphie et paléodiversité - Geobios 32: 353-364.

Wani, R., Kase, T., Shigeta, V. \& Ocampo, R. 2005. New look at ammonoid taphonomy, based on field experiments with modern chambered nautilus. - Geology 33: 849-852.

Webby, B. D., Cooper, R. A., Bergström, S. M. \& Paris, F. 2004. Stratigraphic framework and time slices. In Webby, B. D., Paris, F., Droser, M. \& Percival, I. (eds). The Great Ordovician Biodiversification Event. Columbia University Press, New York: pp. 41-51.

Webby, B. D., Percival, I. G., Edgecombe, G. D., Cooper, R. A., Vandenberg, A. H. M., Pickett, J. W., Pojeta, J., Playford, G., Winchester-Seeto, T., Young, G. C., Zhen, Y. Y., Nicoll, R. S., Ross, J. R. P. \& Schallreuter, R. 2000. Ordovician palaeobiogeography of Australia. In Wright, A. J., Young, G. C., Talent, J. A. \& Laurie, J. R. (eds). Palaeobiogeography of Australian faunas and floras. - Memoir of the Association of Australian Palaeontologists 23: $63-125$.

Westermann, G. E. D. 1977. Form and function of orthoconic cephalopod shells with concave septa. - Paleobiology 3: 300-321.

Westermann, G. E. D. 1985. Post-mortem descent with septal implosion in Silurian nautiloids. - Paläontologische Zeitschrift 59: 79-97.

Westermann, G. E. D. 1998. Life habits of nautiloids. In Savazzi, E. (ed.). Functional morphology of the invertebrate skeleton. John Wiley, Chichester, New York: pp. 263-298.

Whitfield, R. P. 1886. Notice of geological investigations along the eastern shore of Lake Champlain conducted by Prof. H. M. Seely and Prest Ezra Brainerd, of Middlebury College, with descriptions of the new fossils discovered. - Bulletin of the American $\mathrm{Mu}$ seum of Natural History 1: 293-345.

Wilson, J. L. 1954. Late Cambrian and Early Ordovician Trilobites from the Marathon Uplift, Texas. - Journal of Paleontology 28: 249-285.

Xu, G. \& Lai Cai-gen 1987. Cephalopods. In Biostratigraphy of the Yangtze Gorge area, vol. 2. Early Palaezoic area. Geological Publishing House, Beijing: pp. 245-340 [In Chinese]

Zhuravleva, F. A. 1964. New Ordovician and Silurian cephalopods from the Siberian platform. - Paleontological Journal 4: 87-100.

Zhuravleva, F. A. 1994. The order Dissidocerida (Cephalopoda). - Paleontological Journal 28: 115-132.

Zittel, K. A. von. 1900. Text-book of paleontology (translated and edited by C. R. Eastman). Volume 1. Macmillan \& Co. Ltd., London, New York. 